\title{
ÜNYE ÇAMLIK FENERALTI MEZARLIĞI MEZAR TAŞLARI VE KITABELERI*
}

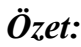

Şerife TALI $\dot{I}^{* *}$

Gelenekler ve dönemin üslup özellikleri ile birlikte şekillenen mezar taşları, toplumun kendi öz değerlerini geleceğe taşıyan en önemli yazllı belgelerdir. Toplumlara ve kültürlere göre bu gelenek malzeme, bezeme ve biçim olarak değişiklik gösterse de ölen kişiyi kalıcı kılabilmek ve onun adına bir işaret koyabilmek hep en önemli amaç olmuştur. Mezar taşı kitabeleri, kültürel ve sanatsal özelliklerinin yanı sıra kabirde yatan kişinin mesleği, unvanı ve onun inanışıyla ilgili önemli verilerin elde edildiğ $i$ edebi birer eser niteliğindedir.

Taş ve mermer üzerine Osmanlıca yazılan mezar taşı kitabelerinin giriş cümleleri genellikle Arapça olarak yazılmıştır. Sülüs, talik gibi hatlarla farklı istiflerle, özel bir işçilikle özenle oluşturulan çerçeveler içerisine yazı kuşakları diyagonal veya düz satırlar hâlinde kazınmıştır. Kitabeler amacına uygun olarak Allaha yakarışla başlayarak, mezarda yatan kişinin kimlik bilgilerinin verildiği bunun yanı sıra ölüm sebepleri, hastalık, ayrılık, sevgi, hüzün gibi detayların da işlendiği önemli belgelerdir. Kısa ve yalın tutulan kitabeler ise ölünün kimlik bilgileri, ruhuna istenen dualar ve tarih ibaresi ile tamamlanmaktadır. Ayrıca kalıp şeklinde yazılan duaların yer aldığı kitabeler de bulunmaktadır. Bu çalışmada Ünye Çamlık Feneraltı Mezarlığında bulunan XVIII.-XX. yy. Osmanl Dönemine ait mezar taşlarl detayl bir şekilde incelenerek, birer belge olan kitabeler değerlendirilmiştir.

Anahtar kelimeler: Ünye, mezar taşı, kitabe, hat, sanat.

\footnotetext{
* $\quad$ Bu makale 27 Nisan - 1 Mayıs 2016 tarihleri arasında Türk Dil Kurumu ve Kosova Cumhuriyeti Priștine Üniversitesi Filoloji Fakültesi işbirliğinde Priştine ve Prizren'de düzenlenen "Milletlerarası Arap Harfli Mezar Taşları ve Yazıtlar Çalıstayı'nda" sunulan bildirinin genişletilmesi ile hazırlanmıștır.

** Doç. Dr., Ordu Üniversitesi Edebiyat Fakültesi Sanat Tarihi Bölümü, talisanat@hotmail.com.
} 


\section{Gravestone Inscriptions at Cemetery of Feneralti of Unye}

\section{Abstrac:}

Gravestones shaped by the traditions and stylistic characteristics of the period are the most important written documents carrying their own values of comunity to the future. Altough the tradition change according to the society and culture, in terms of material,form and decoration, it is the most important goal to make the death person permanent and to put asign for him. Tombstone inscriptions that cultural and artistic features as well as his title and belief the profession of the person lying in the grave has been obtained the important data it a literary work is intended as. Introduction sentences of tombstone inscriptions written in Ottoman Turkish on stone and marble were usually written in Arabic. Sülüs and Ta'lik as with differernt stacks, special workmanship, diagonal or straight lines etched into it writing lines carefully created within the frames. Inscriptions that his purposes starting with God prayer are also important documents given the information of the identitly of the person who lies in the grave and also cause of death, ilness, separation, love, sadness as details are processed. Inscriptions, kept short and simple, complmented by the credentials of dead, requested prayers to the spirit and the date marked. Also there are inscriptions that in prayers written the as form mold. In this study, tombstones by examining in detail a document which inscriptions will be evaluated from XVIII. XX. yy. of the Ottoman Period at Cemetery of Çamlık Feneraltı of Unye.

Keywords: Unye, gravestone, inscription, calligraphy, art.

\section{Giriş}

Ordu iline bağlı Ünye ilçesi doğusunda Fatsa, batısında Terme, kuzeyinde Karadeniz ve güneyinde Akkuş ilçeleri ile sınırlıdır. Taşhâne Burnu üzerinde kurulan ilçe tarih olarak Paleolitik Döneme kadar inmektedir. Türk dönemi olarak Anadolu Selçuklu, Beylikler ve özellikle Osmanlı Döneminde Ünye önemli bir liman kenti ve ticaret merkezidir. Evliya Çelebi 1640 yllında Ünye'yi ziyaret ettiğinde, kitabında Ünye'nin "Ünyes" adında bir hükümdar tarafindan kurulduğunu ve adının da oradan geldiğini ifade etmektedir. XVI. ve XVII. yüzyıllarda Karadeniz sahilinde en mühim ticaret iskelesi Ünye'dir. Eflak, Boğdan, Ukrayna ve Karadeniz havzası tüccarları Diyarbakır ve Halep'ten getirdikleri ticari malları Ünye üzerinden gemilerle nakletmişlerdir. O dönemde Ünye'de mühim bir tersanenin de mevcudiyeti bilinmektedir. XIX. yüzyılın başlarında ise Canik bölgesinin idarecisi olan Süleyman Paşa Ünye'de güzelliği dillere destan büyük bir sahil sarayı yaptırmıştır. Bu saray, sonraları bir yangında tamamen harap olmuştur (Argan: 2004, 17-19; https:// www.unye.bel.tr).

Ölüme rağmen ölümsüzlüğün temsili olarak dikilen mezar taşları Sanat Tarihi araştırmalarının en önemli alanlarından biridir. Şahidelerin üzerinde yer alan kitabeler, kitabelerin içeriğindeki tarihi bilgi ve edebî metinler, lahit 
ve ayak taşları üzerindeki dekoratif bezemeleri ile mezar taşları tarihi birer belgedir. Sadece tarihi bilgilerin değil aynı zamanda din, sosyal ve kültürel açıdan da o yerle ilgili detaylı verilerin elde edildiği mezar taşları geçmişin canlı şahitleridir. Sanat tarihi metodolojisi içerisinde incelediğimiz Çamlık Feneraltı Mezarlığı zengin bir geçmişi barındırmaktadır. Mezarlıkta çok sayıda muhacirin defnedildiği, farklı meslek grubuna ait insanların defnedildiği özellikle de erkek nüfusun ağırlıkta olduğu anlaşılmaktadır. Şahidelerden dönemle ilgili en doğru bilgiler elde edilmiş, yazılı belgeler olarak mezar taşları sanat tarihi açısından dönemin üslup özellikleri hakkında fikirler vermiştir. Malzeme, hat ve işçilik açısından Feneraltı Mezarlı̆̆ı, mezar taşlarının itinalı ve başkent İstanbul örneklerine paralellikler göstermesi önemlidir. Mezarlıkta tahribat nedeniyle pek çok örnek yerlerinden çıkarılmış veya yok olmuş, özellikle son dönemde restorasyon amaçlı yapılan müdahaleler kitabelerin erimesine sebep olmuştur. Her türlü olumsuz müdahaleye rağmen günümüze ulaşan mezar taşları bu çalışma ile kronolojik olarak ele alınmış ve belgelenmiştir.

\section{Çamlık Mezar Taşları}

\section{Mezar Taşı No: 1}

\section{Kitabesi:}

Ziyaretten Murad Olan Dua'dır

Bugün Bana İse Yarın Sanadır

Merhum ve Mağfur Terzi Ali

Oğlu Hasan Yazıcı

Ruhuna Fatiha

Sene 1183/1769-1770 (lam-Şevval)

Mezar Tipi: Şahideli Toprak Mezar

Ölçüler: Baş taş1: 65x26x14 cm., Boyun: 18x42 cm., Başlık: 18x83 cm.

Tanım: Mermerden yapılan baş taşı dikdörtgen kesitli düşey dikdörtgen prizmal bir gövdeye sahiptir. Kitabe düz silmelerle ayrılan dikdörtgen panolar içerisine beş satır hâlinde celi sülüs hatla kabartma olarak yazılmıştır. Kitabenin tarih ibaresinin olduğu son satırı dilimli bir kartuşla hareketlendirilmiştir. Baş taşı, boyun üzerinde kavuk biçiminde bir başlıkla tamamlanmıştır.

Mezar Taşı No: 2

\section{Kitabesi:}

Ah Mine'l Mevt

Gel Efendim Nazar Eyle Şu Mezar Taşına

Akil İsen Gafil Olma Aklını Al Başına 
Bende Senin Gibi Gezerdim Bak Ne Geldi Başıma

(Akıbet) Turâb Oldum Taş Dikdiler Başıma

Trabzonlu ....̇̇smail Zade

Ali..Efendi ...?

Hanım Ruhuna Fatiha 1234/1818-1819

Mezar Tipi: Şahideli Üzeri Açık Lahit Mezar

Ölçüler: Baş taş1: 70x28-24x8 cm., Ayak taş1: 62x26-24x11 cm., Lahit: $131 \times 251 \times 67 \mathrm{~cm}$.

Tanım: Mermerden yapılan baş taşının dikdörtgen kesitli düşey dikdörtgen prizmal gövdesi üstte sivri kemer formlu bir tepelikle tamamlanmıştır. Şahidenin kitabesi düz silmelerle ayrılan dikdörtgen panolar içerisine sekiz satır hâlinde nesih hatla kabartma olarak yazılmıştır. Sivri kemer formlu bir tepelikle sonlanan ayak taşı sadedir.

Mezar Taşı No: 3

\section{Kitabesi:}

Hüve'l-Baki

Beni K1l Mağfiret Ey Rabb-i Yezdan

Gelüb Kabrimi Ziyaret Eden İhvan

İdeler Ruhuma Fatiha

Terzi Ali Zade Merhum

Muhammed Yazıcının Zevcesi

Penpe Hanım Ruhuna Fatiha

Sene 1261/1846-1847

Mim (Muharrem) 15..?

Mezar Tipi: Şahideli Toprak Mezar

Ölçüler: Baş taş1: 100x40-30x10 cm.

Tanım: Mermerden yapılan baş taşının dikdörtgen kesitli düşey dikdörtgen prizmal gövdesi yukarı doğru genişleyerek üçgen bir tepelikle tamamlanmıştır. Kitabe düz silmelerle ayrılan dikdörtgen panolar içerisine sekiz satır hâlinde celi sülüs hatla kabartma olarak yazılmıştır.

Mezar Taşı No: 4

\section{Kitabesi:}

Hüve'l-Baki

Olıcak Ferman Hak İster İcabet-i Davete

Emrine Muti' Olan Cümle İrerler İzzete 
Azm idüb Beka Mülküne Bir Merd Sihr

El çeküb Fani Cihandan İrdi Kurb-i Rahmete

Hayatında Ruz-i Şeb İkram İderdi Âleme

Hanesinde Nice Kimseye Sunardı Nimete

Adalı Zade Merhum El Hac

Hüseyin Ağa Ruhuna El Fatiha

Sene 1264/1847-1848

Mezar Tipi: Şahideli Toprak Mezar

Ölçüler: Baş taşı: 85x30x17 cm., Boyun: 8x44 cm., Başlık: 22x76 cm.

Tanım: Mermerden yapılan baş taşının dikdörtgen kesitli düşey dikdörtgen prizmal gövdesi dalgalı bir forma sahiptir. Kitabe, silmelerle sinırlanan diyagonal çerçeveler içerisine on satır hâlinde celi sülüs hatla kabartma olarak yazılmıştır. Şahidenin gövde kısmında kemer köşelikleri çiçek motifleri ile bezenmiştir. Baş taşı boyun üzerinde sarık biçiminde bir başlıkla tamamlanmıştır.

\section{Mezar Taşı No: 5}

\section{Kitabesi:}

Hüve'l-Baki

Beni Kıl Mağfiret Ya Rabb-i Gufran

Bi Hakk-1 Arş-1 Azam Nur-u Kur'an

Gelüb Kabrimi Ziyaret Eden İhvan

Ruhuma İde Bir Fatiha İhsan

Küblü Oğlu Abdi İsmet?)

Yazıcının Mahdumu Ahmet

Efendinin Ruhiyçün Fatiha

Sene 1306/1888-1889

Mezar Tipi: Şahideli Çerçeve Mezar

Ölçüler: Baş taş1: 90x33-24x10 cm., Boyun: 8x44 cm., Başlık: 20x55 cm., Ayak taş1: 85x30-25x7 cm.

Tanım: Mermerden yapılan baş taşının dikdörtgen kesitli düşey dikdörtgen prizmal gövdesi yukarı doğru genişlemektedir. Kitabe düz silmelerle ayrılan dikdörtgen panolar içerisine dokuz satır hâlinde celi sülüs hatla kabartma olarak yazılmıştır. Baş taşı boyun üzerinde fes biçiminde bir başlıkla tamamlanmıştır. 
Mezar Taşı No: 6

Kitabesi:

Hüve'l-Baki

Ya İlahi Ruz-i Mahşerde Bana Lütfeyle

Ne Dertten Helak Oldum Şehitlerle Haşr-Eyle

Sana Kurban İdib Canım Eyledim Turab-1 Mesken

Cismanîm Ab-1 Rahmetinle Gel İsyanım Affeyle

Ünye Karantina? Memuru Osman

Nuri Efendinin Ruhuna Fatiha

Sene 1318/1902-1903 Sene 1316/1900-1901

Arabi Berat Gecesi Rumi

\section{Mezar Tipi: ?}

Ölçüler: Baş taş1: 72x33-26-33x8 cm., Boyun: 7x50 cm., Başlık: 11x62 cm., Ayak taş1: 90x26-17x8 cm.

Tanım: Mermerden yapılan baş taşının düşey dikdörtgen prizmal gövdesi alt kısımda oval olup üste doğru daralarak devam etmektedir. Kitabe, silmelerle sınırlanan diyagonal çerçeveler içerisine on satır hâlinde celi talik hatla kabartma olarak yazılmıştır. Şahidenin kenarları alt kısımda akanth yaprakları ile sınırlanmıştır. Baş taşı boyun üzerinde fes biçiminde bir başlıkla tamamlanmıştır. Ayak taşı sivri kemer formlu bir tepelikle sonlanırken yüzeyi palmetten çıan soyut dallar üzerinde çiçek ve yaprak motifleri ile bezenmiştir(Ayaktaşı No:10).

\section{Mezar Taşı No: 7}

\section{Kitabesi:}

Ah Mine'l-Mevt

Ey Fani'nin Bağ-1 Cihanı Bana Zindan Eyledin

Servetim Yedin Aldın Beni Seraba Saldın

Ailemi Ah-1 Fenaya Düşürüp Ciğerlerini ... Eyledin

Bir Devasız Derde Düşüp Emr-i Düçar Eyledin

Gelüb Kabrimi Ziyaret Eden Mü'min Gardeşlerim

Merhamet Ruhuma Bir Fatiha İhsan Eylesin

Vakfikebirli Osman Baş Oğlu Osman'ın

Oğlu Şükrü ... İrtihali Ruhuna Fatiha

1325/ 1907-1908 Vefatı Mahrumun

Mezar Tipi: Şahideli Üzeri Açık Lahit Mezar 
Ölçüler: Baş taşı: 65x28-25x7 cm., Boyun: 8x44 cm., Başlık: 16x54 cm., Ayak taş1: 80x28-25x7 cm., Lahit: 151x267x97 cm.

Tanım: Mermerden yapılan baş taşının dikdörtgen kesitli düşey dikdörtgen prizmal gövdesi yukarı doğru genişleyerek tamamlanmıştır. Şahidenin kitabesi serbest on satır hâlinde diyagonal biçimde celi talik hatla kabartma olarak yazılmıştır. Baş taşı boyun üzerinde fes biçiminde bir başlıkla tamamlanmıştır. Sivri kemer formlu tepelikle sonlanan ayak taşı sadedir.

Mezar Taşı No: 8

\section{Kitabesi:}

Eyle Rağbet bi Dehrî Der...

On Sekizinde Bir Nev-civanın (?)

Hüsnü Zan Olmuştu Hak ide Rahmet

Talib İlmi Hafiz Kelamı

... Medrese Sebep Mevlâ...Heft.?

Üç yüz otuz Saferinden ...?

(Çela?)dırlı Ahmedin Tarih-i Vefatı

Hep Görenler Fatiha Okusun (Kabire)

Sene (tis'a 1şreyn ve selasemieh ve elf)

1329/1911

Mezar Tipi: Şahideli Üzeri Açık Lahit Mezar

Ölçüler: Baş taş1: 90x33x8 cm., Boyun: 7x45 cm., Başlık: 20x60 cm., Ayak taş1: 62x28-22x5 cm., Lahit: 135x200x77 cm.

Tanım: Mermerden yapılan baş taşı dikdörtgen kesitli düşey dikdörtgen prizmal bir gövdeye sahiptir. Şahidenin kitabesi serbest olarak düz satırlar hâlinde nesih hatla kabartma olarak yazılmıştır. Baş taşı boyun üzerinde fes biçiminde bir başlıkla tamamlanmıştır. Üçgen bir tepelikle sonlanan ayak taşında yelpazeye benzer farklı bir motif ile bezenmiştir (Ayak Taşı No:4).

Mezar Taşı No: 9

\section{Kitabesi:} .(kırılmış)

Göreleli Kara Hacı Oğlu

Ali Haydar Efendinin

Ruhuna Fatiha

19 Kânun-u Sâni (Ocak) 1332/1913-1914

Mezar Tipi: Şahideli Üzeri Açık Lahit Mezar 
Ölçüler: Baş taş1: 45x28-25x7 cm., Ayak taş1: 70x27-25x7 cm., Lahit: $103 \times 227 \times 80 \mathrm{~cm}$.

Tanım: Mermerden yapılan baş taşının dikdörtgen kesitli düşey dikdörtgen prizmal bir gövdeye sahip olup üst kısmı kırılmıştır. Kitabe düz silmelerle ayrılan dikdörtgen panolar içerisine celi sülüs hatla kabartma olarak yazılmıştir.

Mezar Taşı No: 10

Kitabesi:

Ah Mine'l-Mevt

Beni K1l Mağfiret Ya Rabb-i Gufran

Bi Hakk-1 Arş-1 Azam Nur-1 Kur'an

Gelib Kabrim Ziyaret (İden) İnsan

Ede Bir Fatiha Ruhuma İhsan

Trabzon Muhacirlerinden

Karyesinden Ali Efendi Zade Fehmi

Ruhuna Fatiha 1332/1913-1914 Recep

Mezar Tipi: Şahideli Toprak Mezar

Ölçüler: Baş taşı: 83x33-28x10 cm., Başlık:16x52 cm. Ayak taşı: 84x32$29 \times 10 \mathrm{~cm}$.

Tanım: Mermerden yapılan baş taşının dikdörtgen kesitli düşey dikdörtgen prizmal gövdesi yukarı doğru genişlemektedir. Kitabe düz silmelerle ayrılan dikdörtgen panolar içerisine nesih hatla kabartma olarak yazılmıştır. Baş taşı boyun üzerinde fes biçiminde bir başlıkla tamamlanmıştır. Sivri kemer formlu tepelikle sonlanan ayak taşı sadedir.

Mezar Taşı No: 11

Kitabesi:

Ah Mine'l-Mevt

..? Gazasindan..

Garyesinden Fıldır

Oğlu Hacı Mustafanın

Zevcesi Gülfizar Hatunun

Ruhuna Fatiha

13 Kânun-u Sâni (Ocak)

1332/1913-1914

Mezar Tipi: Şahideli Toprak Mezar 
Ölçüler: Baş taş1: 76x31-26x10 cm., Ayak taş1: 79x30-26x10 cm.

Tanım: Mermerden yapılan baş taşının dikdörtgen kesitli düşey dikdörtgen prizmal gövdesi yukarı doğru genişleyerek oval bir tepelikle sonlanmaktadır. Kitabe serbest sekiz satır hâlinde celi sülüs hatla kabartma olarak yazılmıştır. Sivri kemer formlu tepelikle sonlanan ayak taşı sadedir.

Mezar Taşı No: 12

\section{Kitabesi:}

Ah Mine'l-Mevt

Gel Efendim Nazar Eyle Şu Mezar Taşına

Akı1 İsen Gafil Olma Aklını Al Başına

Salınıp Gezerdim Bak Ne Geldi Başıma

Akıbet Turab Oldum Taş Diktiler Başıma

Rizeli Ekşi Zade Hacı

Sadığın Zevcesi Fatıma Hanımın

Ruhuna Fatiha 1332/1914-1915

Mezar Tipi: Şahideli Üzeri Açık Lahit Mezar

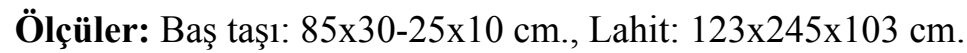

Tanım: Mermerden yapılan baş taşının dikdörtgen kesitli düşey dikdörtgen prizmal gövdesi üstte sivri kemer formlu bir tepelikle tamamlanmıştır. Kitabe düz silmelerle ayrılan dikdörtgen panolar içerisine sekiz satır hâlinde celi talik hatla kabartma olarak yazılmıştır.

Mezar Taşı No: 13

\section{Kitabesi:} .(silinmiş)

Rizeli .....

Oğlu Kerimesi

Ruhuna Sene 1332/1913-1914

\section{Mezar Tipi: ?}

Ölçüler: Baş taş1: 88x28-26x12 cm.

Tanım: Mermer malzemeden yapılan baş taşının dikdörtgen kesitli düşey dikdörtgen prizmal gövdesi sivri kemerli bir tepelikle sonlanmaktadır. Üst k1sımda tamamen tahrip olan kitabe serbest olarak yazılmıştır.

Mezar Taşı No: 14

\section{Kitabesi:}

Ah Mine'l Mevt 
Emr Etdi Huda Eyledi Ferman

Validem Ah İdib Eyleme Figan

Murada Ermedim Dünyada Heman

Cennette Vere Muradım Halik-1 Rahman

Uzun Hacı Oğlu Muhammedin

Mahdumu Merhum Ahmet Ruhuna

Sene 1332/1913-1914

Mezar Tipi: Şahideli Toprak Mezar

Ölçüler: Baş taş1: 60x20x12 cm., Boyun: 7x35 cm., Başlık: 14x55 cm., Ayak taş1:81x30-23x6 cm.

Tanım: Mermerden yapılan baş taşı dikdörtgen kesitli düşey dikdörtgen prizmal bir gövdeye sahiptir. Kitabe, silmelerle sınırlanan diyagonal çerçeveler içerisine sekiz satır hâlinde celi talik hatla kabartma olarak yazılmıştır. Baş taşı boyun üzerinde sola doğru sarkıtılan püsküllü fes biçiminde bir başlıkla tamamlanmıştır. Sivri kemer formlu tepelikle sonlanan ayak taşı sadedir.

Mezar Taşı No: 15

\section{Kitabesi:} .(kırık).

Civelek Zade Hüseyin

Bin ..Kapdan Bin Mehmed Efendi

Ruhuna Fatiha

1332/1913-1914

\section{Mezar Tipi: Şahideli Üzeri Açık Lahit Mezar}

Ölçüler: Baş taş1: 80x30-23x10 cm., Ayak taş1: 82x30-26x8 cm.

Tanım: Mermerden yapılan baş taşının dikdörtgen kesitli düşey dikdörtgen prizmal gövdesi üst kısımda kırılmıştır. Kitabe düz silmelerle ayrılan dikdörtgen panolar içerisine celi talik hatla kabartma olarak yazılmıştır. Sivri kemer formlu tepelikle sonlanan ayak taşı sadedir.

Mezar Taşı No: 16

\section{Kitabesi:}

Ah Mine'l-Mevt

Beni Kı1 Mağfiret Ya Rabb-i Gufran

Bi Hakk-1 Arş-1 Azam Nur-1 Kur'an

Gelib Kabrim Ziyaret İden İnsan

İde Bir Fatiha Ruhuma İhsan 
Göreleli K1lıç Oğlu

Abdullah Efendinin

Ruhuna Fatiha

1333/1914-1915

Mezar Tipi: Şahideli Çerçeve Mezar

Ölçüler: Baş taşı: 60x28-25x9 cm., Boyun:13x40 cm., Başlık: 16x50 cm. Ayak taş1: $65 \times 23 \times 8 \mathrm{~cm}$., Lahit: 155x328x61 cm.

Tanım: Mermerden yapılan baş taşının dikdörtgen kesitli düşey dikdörtgen prizmal gövdesi yukarı doğru genişlemektedir. Kitabe serbest dokuz satır hâlinde celi sülüs hatla kabartma olarak yazılmıştır. Baş taşı boyun üzerinde fes biçiminde bir başlıkla tamamlanmıştır. Ayaktaşının geometrik motiflerle bezenen dikdörtgen prizmal gövdesi üçgen bir tepelikle sonlanmıştır(Ayak Taş1 No:9).

\section{Mezar Taşı No: 17}

\section{Kitabesi:}

Ah Mine'l-Mevt

Bir Kuş İdim Uçdum Yuvadan

Ecel Beni Ayırdı Anadan Babadan

Unutmayın Beni Hayır Duadan

Şefaat Dilerim Sizlere Huda'dan

Hopa Eşrafından Çiçek

Zade Tevfik Efendinin

Ruhuna Fatiha

1333/1914-1915

Mezar Tipi: Şahideli Üzeri Açık Lahit Mezar

Ölçüler: Baş taşı: 65x30-20x8 cm., Boyun: 8x34 cm., Başlık: 14x50 cm., Ayak taşı: $75 \times 27-21 \times 7 \mathrm{~cm}$.

Tanım: Mermerden yapılan baş taşının dikdörtgen kesitli düşey dikdörtgen prizmal gövdesi yukarı doğru genişlemektedir. Kitabe düz silmelerle ayrılan dikdörtgen panolar içerisine dokuz satır hâlinde celi sülüs hatla kabartma olarak yazılmıştır. Baş taşı boyun üzerinde fes biçiminde bir başlıkla tamamlanmıştır. Ayak taşı sivri kemer formlu bir tepelikle sonlanırken yüzeyi vazodan çıkan soyut dallar üzerinde çiçek ve yaprak motifleri işlenmiştir (Ayak Taşı No:5). 
Mezar Taşı No: 18

Kitabesi:

Bir Kuş İdim Uçdum Yuvadan

Ecel Beni Ayırdı Anadan Babadan

Unutmayın Beni Hayır Duadan

Şefaat Dilerim Sizlere Huda'dan

Hopa Eşrafından Çiçek Zade

Tevfik Efendinin Mahdumu

Ali Riza Efendinin Ruhuna

Fatiha 1333 /1914-1915

\section{Lahit üzerinde Yer Alan Kitabeler}

Hopa Eşrafindan Çiçek Zade Tevfik

Efendinin Ruhuna Fatiha 1333 /1914-1915

Hopa Eşrafından Çiçek Zade Tevfik Efendinin

Mahdumu Ali Riza Efendinin Ruhuna Fatiha 1333 /1914-1915

Mezar Tipi: Şahideli Üzeri Açık Lahit Mezar

Ölçüler: Baş Taş1: 52x28-22x8 cm., Boyun: 9x38 cm., Başlık: 15x54 cm.,

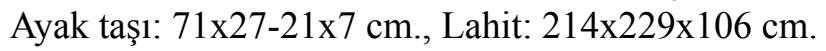

Tanım: Mermerden yapılan baş taşının dikdörtgen kesitli düşey dikdörtgen prizmal gövdesi yukarı doğru genişlemektedir. Kitabe düz silmelerle ayrılan dikdörtgen panolar içerisine sekiz satır hâlinde celi sülüs hatla kabartma olarak yazılmıştır. Baş taşı boyun üzerinde fes biçiminde bir başlıkla tamamlanmıştır. Ayak taşı sivri kemer formlu bir tepelikle sonlanırken yüzeyi vazodan çıkan soyut dallar üzerinde stilize edilmiş üzüm ve asma yaprakları işlenmiştir (Ayak Taşı No:6).

Mezar Taşı No: 19

Kitabesi:

Ah Mine'l Mevt

Batum Muhacirlerinden

Kaytan Oğlu İsmail

Ağanın Ruhuna Fatiha

1333/1914-1915

Mezar Tipi: Şahideli Toprak Mezar 
Ölçüler: Baş taş1: 63x32-27x9 cm., Boyun: $5 \times 42 \mathrm{~cm}$., Başlık:16x53 cm., Ayak taşı: $98 \times 32-26 \times 6 \mathrm{~cm}$.

Tanım: Mermerden yapılan baş taşının dikdörtgen kesitli düşey dikdörtgen prizmal gövdesi yukarı doğru genişlemektedir. Kitabe düz silmelerle ayrılan dikdörtgen panolar içerisine beş satır hâlinde celi sülüs hatla kabartma olarak yazılmıştır. Baş taşı boyun üzerinde fes biçiminde bir başlıkla tamamlanmıştır. Sivri kemer formlu tepelikle sonlanan ayak taşı sadedir.

Mezar Taşı No: 20

\section{Kitabesi:} ...(kırılmış)

Ruhuma Bir Fatiha Eyleye İhsan

Trabzon Mülteciyândan Kara Mahmud

Oğlu Raşid Ruhuna Fatiha

1333/1914-1915

Mezar Tipi: Şahideli Üzeri Açık Lahit Mezar

Ölçüler: Baş taş1:32x26-25x10 cm., Lahit: 114x260x60 cm.

Tanım: Mermerden yapılan baş taşının dikdörtgen kesitli düşey dikdörtgen prizmal gövdesi üst kısımda kırılmıştır. Kitabe, silmelerle sınırlanan diyagonal çerçeveler içerisine celi sülüs hatla kabartma olarak yazılmıştır.

Mezar Taşı No: 21

\section{Kitabesi:}

Sene 1333/1914-1915

Bu Fenada Kıldım Gayret Bir Zaman

İrdi Ecel Vermedi Bana Aman

Mağfiret Kıl Beni Ey Rabb-i Yezdan

Bi Hürmeti Bi Kabr-i Ahir Zaman

Rize Muhacirlerinden Trabzonlu Sufi

Zade Mehmet Ustanın Ruhuna Fatiha

\section{Mezar Tipi: ?}

Ölçüler: Baş taş1: 65x27-24x9 cm., Boyun: 8x51 cm., Başl1k: 16x52 cm.

Tanım: Mermerden yapılan baş taşının dikdörtgen kesitli düşey dikdörtgen prizmal gövdesi yukarı doğru genişlemektedir. Kitabenin ilk dört satırı düz silmelerle ayrılan dikdörtgen panolar içerisine diğer satırlar ise serbest olarak celi sülüs hatla kabartma olarak yazılmıştır. Baş taşı boyun üzerinde fes biçiminde bir başlıkla tamamlanmıştır. 
Mezar Taşı No: 22

\section{Kitabesi:}

Hüve'l-Baki

İbret Al Benden Taze Girdim

Ünyeden Hatip Oğlu

Resul Bin Hüseyin

Sene

1333/1914-1915

Mezar Tipi: Şahideli Toprak Mezar

Ölçüler: Baş Taş1: 40x30-26x8 cm., Boyun: 5x35 cm., Başlık: 15x44 cm., Ayak taşı: $53 \times 30-25 \times 8 \mathrm{~cm}$.

Tanım: Mermerden yapılan baş taşının dikdörtgen kesitli düşey dikdörtgen prizmal gövdesi yukarı doğru genişlemektedir. Kitabe düz silmelerle ayrılan dikdörtgen panolar içerisine altı satır hâlinde celi sülüs hatla kabartma olarak yazılmıştır. Baş taşı boyun üzerinde fes biçiminde bir başlıkla tamamlanmıştır. Ayak taşı üçgen kemer formlu bir tepelikle sonlanırken yüzeyi soyut dallar ve yapraklar arasında servi motifi ile bitkisel bir kompozisyon işlenmiştir (Ayak Taş1 Fot. No:2).

Mezar Taşı No: 23

\section{Kitabesi:}

Hüve'l-Baki

İlahi Ente Maksudi

Affet Kulun Şaban'1

Bi Hürmet-i'l Fatiha Hakk

Sene 1333/1914-1915

Mezar Tipi: Şahideli Toprak Mezar

Ölçüler: Baş taş1: 45x27x9 cm., Boyun: $5 \times 35 \mathrm{~cm}$., Başlık: 15x50 cm., Ayak taşı: ?

Tanım: Mermerden yapılan baş taşının dikdörtgen kesitli düşey dikdörtgen prizmal gövdesi yukarı doğru genişlemektedir. Kitabe düz silmelerle ayrılan dikdörtgen panolar içerisine beş satır hâlinde celi sülüs hatla kabartma olarak yazılmıştır. Baş taşı boyun üzerinde fes biçiminde bir başlıkla tamamlanmıştır. Ayak taşı sivri kemer formlu bir tepelikle sonlanırken yüzeyi soyut dallar üzerinde çiçek ve yaprak motifleri ile bezenmiştir (Ayak Taşı Fot. No:3). 


\section{Mezar Tașı No: 24}

\section{Kitabesi:}

Ziyaret Eyleyin Şu (suha?) Kabri

Fikirden (ak1l) İsen Cenab-1 Hüda'ya

Burdadır Mağfiret Ruhu Şad Olsun

Bir Din ....Bizlere Yavi

Ecel Geldi Ömrüm İncâh Erdi

Ki Zira ... Oldu Emr-i İlahi

..Zade Yakup Efendi Ruhuna Fatiha 1333/1914-1915

Mezar Tipi: Şahideli Üzeri Açık Lahit Mezar

Ölçüler: Baş taş1: 55x27-25x7 cm., Lahit: 113x303x45 cm.

Tanım: Mermerden yapılan baş taşının dikdörtgen kesitli düşey dikdörtgen prizmal gövdesi yukarı doğru genişlemektedir. Kitabe düz silmelerle ayrılan dikdörtgen panolar içerisine sekiz satır hâlinde nesih hatla kabartma olarak yazılmıştır. Baş taşı boyun üzerinde fes biçiminde bir başlıkla tamamlanmıştır.

\section{Mezar Taşı No: 25}

\section{Kitabesi:}

$$
\text { 1333/1914-1915 }
$$

Ah Mine'l-Mevt

Beni K1l Mağfiret Ey Rabb-i Yezdan

Bi Hakk-1 Arş-1 Azam Nur-1 Kur'an

Gelüb Kabrimi Ziyaret İden İhvan

İdeler Ruhuma Bir Fatiha İhsan

Akçaşehir Muhacirlerinden ..Oğlu Ahmed

Mezar Tipi: Şahideli Toprak Mezar

Ölçüler: Baş taş1: 70x28-23x8 cm., Ayak taş1: 62×27-23x12 cm.

Tanım: Mermerden yapılan baş taşının dikdörtgen kesitli düşey dikdörtgen prizmal gövdesi üstte sivri kemer formlu bir tepelikle tamamlanmıştır. Şahidenin kitabesi düz silmelerle ayrılan dikdörtgen panolar içerisine yedi satır hâlinde nesih hatla kabartma olarak yazılmıştır. Sivri kemer formlu tepelikle sonlanan ayak taşı sadedir. 
Mezar Taşı No: 26

Kitabesi:

......... Oğlu ............

Ruhuna Fatiha

(1 Mart)..1333/1914-1915

Mezar Tipi: Şahideli Üzeri Açık Lahit Mezar

Ölçüler: Baş taşı: 65x30-26x8 cm., Boyun: 14x43 cm., Başlık: 17x54 cm., Lahit: 120x250x88 cm.

Tanım: Mermerden yapılan baş taşının dikdörtgen kesitli düşey dikdörtgen prizmal gövdesi yukarı doğru genişlemektedir. Tamamen tahrip olan kitabe serbest olarak celi sülüs hatla kabartma olarak yazılmıştır. Baş taşı boyun üzerinde fes biçiminde bir başlıkla tamamlanmıştır.

Mezar Taşı No: 27

\section{Kitabesi:}

1334/1915-1916

Dâr-1 Dünya ....?

Dahılindedir ...................?

..dırlıdan Gogu Zade Hafiz Ruhuna

Fatiha

Mezar Tipi: Şahideli Üzeri Açık Lahit Mezar

Ölçüler: Baş taş1: 68x30-26x12 cm., Boyun: 12x44 cm., Başlık: 20x60 cm., Lahit: $123 \times 248 \times 95 \mathrm{~cm}$.

Tanım: Mermerden yapılan baş taşının dikdörtgen kesitli düşey dikdörtgen prizmal gövdesi yukarı doğru genişlemektedir. Kitabe düz silmelerle ayrılan dikdörtgen panolar içerisine sekiz satır hâlinde celi talik hatla kabartma olarak yazılmıştır. Baş taşı boyun üzerinde fes biçiminde bir başlıkla tamamlanmıştır.

Mezar Taşı No: 28

Kitabesi:

Hüve'l-Baki

Fenadan Bekaya Eyledi Rihlet

İde Hak Kabrini Ravza-i Cennet

İmam Zade Rafet

Efendinin Ruhuna Fatiha 
(5) Sene 1335/1916-1917 Şaban

(15) Sene 1322/1904-1905 May1s

Mezar Tipi: Şahideli Çerçeve Mezar

Ölçüler: Baş taş1: 93x30x7 cm., Boyun: 8x37 cm. Başl1k: 20x66 cm.

Tanım: Mermerden yapılan baş taşı dikdörtgen kesitli düşey dikdörtgen prizmal bir gövdeye sahiptir. Kitabe, düz silmelerle ayrilan dikdörtgen panolar içerisine yedi satır hâlinde celi talik hatla kabartma olarak yazılmıştır. Baş taşı boyun üzerinde sarık biçiminde bir başlıkla tamamlanmıştır.

Mezar Taşı No: 29

\section{Kitabesi:}

Ah Mine'l-Mevt

Fani Dünya Hoşdur Mevt Od

Ünyeden Hatip Oğlu

Hakkı Bin Hüseyin

Sene

1336/1917-1918

Mezar Tipi: Şahideli Toprak Mezar

Ölçüler: Baş taş1: 66x30-23x8 cm., Boyun: 5x34 cm., Başlık: 21x44 cm.

Tanım: Mermerden yapılan baş taşının dikdörtgen kesitli düşey dikdörtgen prizmal gövdesi yukarı doğru genişlemektedir. Kitabe düz silmelerle ayrılan dikdörtgen panolar içerisine altı satır hâlinde celi sülüs hatla kabartma olarak yazılmıştır. Baş taşı boyun üzerinde fes biçiminde bir başlıkla tamamlanmıştır.

Mezar Taşı No: 30

\section{Kitabesi:}

1338/1919

Bakınız İbretle Mezar Taşıma

On Üç Yaşımda Dikdiler Başıma

Hiç Ecel Bir Günde Etti Şikâr

İki Hemşire Yan Yana Yatar

........Eden Ey ....Pur-u Tayyanın

......Gafletten Uyanın

Naili Zade Osman Efendinin

Kerimesi Faika'nın Ruhiyçün Fatiha

Mezar Tipi: Şahideli Üzeri Açık Lahit Mezar 
Ölçüler: Baş taş1: 75x30-25x8 cm., Lahit: 257x259x95 cm.

Tanım: Mermerden yapılan baş taşının dikdörtgen kesitli düşey dikdörtgen prizmal gövdesi yukarıda üçgen bir tepelikle tamamlanmıştır. Kitabe düz silmelerle ayrılan dikdörtgen panolar içerisine dokuz satır hâlinde celi sülüs hatla kabartma olarak yazılmıştır.

Mezar Taşı No: 31

\section{Kitabesi:}

1338/1919

Unutmasın Kimse Fani Dünya Yalan

Çünkü Yoktur Dünyada Hiç Baki Kalan

Akıbet Buradadır Bu Yerdir Akil Ol

Gün İndi Kervan Nazır ...? Son

Muntazır Ol Mevte Daim ..Gözüm?

Metâlibi Sizden Duadır Bu Son Dem

..................................?

Oğlu Ali Mahdumu Mevlüd Ruhuna

Mezar Tipi: Şahideli Üzeri Açık Lahit Mezar

Ölçüler: Baş taş1: 60x27-23x9 cm., Boyun: 5x44 cm., Başlık: 17x53 cm., Ayak taş1: 80x27-24x9 cm. Lahit: 130x248x74 cm.

Tanım: Mermerden yapılan baş taşının dikdörtgen kesitli düşey dikdörtgen prizmal gövdesi yukarı doğru genişlemektedir. Kitabe düz silmelerle ayrılan dikdörtgen panolar içerisine dokuz satır hâlinde celi sülüs hatla kabartma olarak yazılmıştır. Baş taşı boyun üzerinde fes biçiminde bir başlıkla tamamlanmıştır. Sivri kemer formlu tepelikle sonlanan ayak taşı sadedir.

\section{Mezar Taşı No: 32}

\section{Kitabesi:}

1338/1919

Gel? İbret Eyle Bu Taşa

.....................?

Şakir Efendi Zade Nuri Efendinin

Ruhıçün Fatiha

Sene 1338/1919

Mezar Tipi: Şahideli Çerçeve Mezar

Ölçüler: Baş Taşı: 65x28-19x10 cm., Boyun: 7x48 cm., Başlık: 15x50 $\mathrm{cm}$. 
Tanım: Mermerden yapılan baş taşının dikdörtgen kesitli düşey dikdörtgen prizmal gövdesi yukarı doğru genişlemektedir. Kitabe düz silmelerle ayrılan dikdörtgen panolar içerisine sekiz satır hâlinde celi sülüs hatla kabartma olarak yazılmıştır. Baş taşı boyun üzerinde fes biçiminde bir başlıkla tamamlanmıştır.

Mezar Taşı No: 33

Kitabesi:

İbret Al Ey Kişi Bu Taşdan

(Bir) Günde Senin Başına Dikerler

Bugün Firsat Elde İken

Ahret İçin Güzel Amel

Tedarik Edin Odur

................(Kırik)

\section{Mezar Tipi:?}

Ölçüler: Baş taş1: 35x29-27x9 cm.

Tanım: Mermerden yapılan baş taşının dikdörtgen kesitli düşey dikdörtgen prizmal gövdesi alt kısımda kırılmıştır. Kitabe düz silmelerle ayrılan dikdörtgen panolar içerisine celi sülüs hatla kabartma olarak yazılmıştır. Şahidenin başlık kısmı da kırık vaziyettedir.

Mezar Taşı No: 34

\section{Kitabesi:} (Kır1k)

Verecek idi Bir Can?

Arhavili Mehmet Oğlu Şerafeddin

Ruhiyçün El Fatiha

Mezar Tipi: Şahideli Üzeri Açık Lahit Mezar

Ölçüler: Baş taş1: 32x25x9 cm., Ayak taş1: 88x30-25x9 cm., Lahit: 90x247x70 cm.

Tanım: Mermerden yapılan baş taşının dikdörtgen kesitli düşey dikdörtgen prizmal gövdesi üst kısımda kırılmıştır. Kitabe düz silmelerle ayrılan dikdörtgen panolar içerisine celi sülüs hatla kabartma olarak yazılmıştır. Sivri kemer formlu tepelikle sonlanan ayak taşı sadedir.

Mezar Taşı No: 35

Kitabesi:

$\mathrm{Ya} \mathrm{Hu}$

Değildir Durası Sabit (mü)tehallifedir İşi Bir An 
Sana İkbal İder Bir Gün Kullar Ahiresi Büryan

Düşün Dur ta Adadın Bu Eyyama Desin Bir Bak

Neler Gelmiş Hesap Eyle Vefa Bulmuş mu Hiç Bir Can

Ötesi Gün Gibi Zahir Değil mi? Fani Dünyanın

Niçin Sevsin A’nı İnsan Niçin Olsun Ona Hayran

Beniz Genç İken Nâgâh-1 Ecel Sır Etti Gariptir

Şarab-1 Mevti Nuş Ettim Yerim Oldu Bu Kabristan

Halilim? Ünye Taburu Kumandanı Tahir Beydir

....Ruhuna İhsan Edin Bir Fatiha .(gömülü)

Mezar Tipi: Şahideli Toprak Mezar

Ölçüler: Baş taş1: 115x33-29x7 cm. Ayak taşı: 86x30-26x9 cm.

Tanım: Mermerden yapılan baş taşının dikdörtgen kesitli düşey dikdörtgen prizmal gövdesi yukarı doğru genişleyerek bitkisel bir tepelikle tamamlanmıştır. Kitabe düz silmelerle ayrılan dikdörtgen panolar içerisine celi talik hatla kabartma olarak yazılmıştır. Sivri kemer formda tamamlanan ayak taşı ise asma dalları ve üzüm motifleri ile bezenmiştir (Ayak Taş1 Fot. No:8).

Mezar Taşı No: 36

\section{Kitabesi:}

Hüve'l-Baki

Beni K1l Mağfiret Ey Rabb-i Yezdan

Bi Hakk-1 Arş-1 Azam Nur-1 Kur'an

Gelib Kabrimi Ziyaret Eden İhvan

İdeler Ruhuma Bir Fatiha İhsan ( Kırık)

\section{Mezar Tipi: Şahideli Çerçeve Mezar}

Ölçüler: Ayak Taş1: 51x29-25x7 cm., Boyun: 8x45 cm., Başl1k: 25x75 $\mathrm{cm}$.

Tanım: Mermerden yapılan baş taşı dikdörtgen kesitli düşey dikdörtgen prizmal bir gövdeye sahiptir. Şahidenin alt kısmı kırılmıştır. Kitabe, düz silmelerle ayrılan dikdörtgen panolar içerisine beş satır hâlinde celi talik hatla kabartma olarak yazılmıştır. Baş taşı boyun üzerinde sarık biçiminde bir başlikla tamamlanmıştır.

Mezar Taşı No: 37

Kitabesi: 
Hüve'l-Baki

Emir-i Hakla Dürlü Emraz Geldi Benim Tenime

Beni Kıl Mağfiret Ey Rabbi Yezdan

Bi Hakk-1 Arş-1 Azam Nur-i Kur'an

Gelib Kabrimi Ziyaret Eden İhvan

İde Ruhuna Fatiha İhsan

Adalı Zade Merhum El Hac

Hasan Ağa Ruhiyçün El Fatiha ..(gömülü)

Mezar Tipi: Şahideli Toprak Mezar

Ölçüler: Baş Taş1: 78x30x17 cm., Boyun: 10x45 cm., Başl1k: 24x80 cm.

Tanım: Mermerden yapılan baş taşı dikdörtgen kesitli düşey dikdörtgen prizmal bir gövdeye sahiptir. Kitabe, düz silmelerle ayrilan dikdörtgen panolar içerisine sekiz satır hâlinde celi sülüs hatla kabartma olarak yazılmıştır. Baş taşı boyun üzerinde sarık biçiminde bir başlıkla tamamlanmıştır.

Mezar Taşı No: 38

Kitabesi:

Hüve'l-Baki

Gül Gibi Açılmadan Soldum Hele

Zarı Zarı Ağlar Bana Bülbül Bile

Hasret Olub Na-Murad Gitdim Yola

Ruhum Şad Meskenim Cennet Ola

Adalı Zade Hacı Hüseyin Ağanın

Mahdumu ve Merhum Muhammed Ağa ...(gömülü)

Mezar Tipi: Şahideli Toprak Mezar

Ölçüler: Baş taş1: 56x25x15 cm., Boyun: 10x40 cm., Başlık: 22x64 cm.

Tanım: Mermerden yapılan baş taşı dikdörtgen kesitli düşey dikdörtgen prizmal bir gövdeye sahiptir. Kitabe, düz silmelerle ayrılan dikdörtgen panolar içerisine yedi satır hâlinde celi sülüs hatla kabartma olarak yazılmıştır. Baş taşı boyun üzerinde sarık biçiminde bir başlıkla tamamlanmıştır.

Mezar Taşı No: 39

\section{Kitabesi:}

Sene ...?

Göreleli Kadir 
Oğlu Hacı

Mehmed Beyin Kerimesi

Ayşe Hanım Ruhuna

Fatiha

\section{Mezar Tipi: ?}

\section{Ölçüler: ?}

Tanım: Mermerden yapılan baş taşının dikdörtgen kesitli düşey dikdörtgen prizmal gövdesi oval bir tepelikle sonlanmaktadır. Kitabe, düz silmelerle ayrılan dikdörtgen panolar içerisine altı satır hâlinde celi sülüs hatla kabartma olarak yazılmıştır.

\section{Mezar Taşı No: 40}

\section{Kitabesi:}

Ah Mine'l-Mevt

Beni K1l Mağfiret Ey Rabb-i Yezdan

Bi Hakk-1 Arş-1 Azam Nur-1 Kur'an

$$
\text { ........................(Kırık) }
$$

Mezar Tipi: Şahideli Üzeri Açık Lahit Mezar

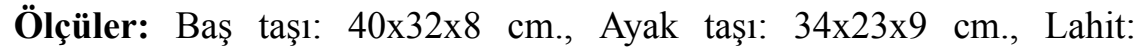
$112 \times 247 \times 106 \mathrm{~cm}$.

Tanım: Mermerden yapılan alt kısmı kırılmış olan baş taşının üstü sivri kemer formlu bir tepelikle tamamlanmıştır. Şahidenin kitabesi serbest olarak celi sülüs hatla kabartma olarak yazılmıştır. Kırılmış hâldeki ayak taşı sivri kemer formlu bir tepelikle sonlanırken yüzeyi soyut dallar üzerinde çiçek ve yaprak motifleri ile bezenmiştir (Ayak Taşı Fot.No:1).

\section{Değerlendirme}

Bu çalışmada Ordu İli Ünye İlçesinde yer alan Çamlık Feneraltı Mezarlığında bulunan tarihî mezar taşları ve kitabeleri incelenmiştir. Günümüzde çoğu mezar taşı kaybolan ve tahrip olan Çamlıktaki tüm örnekler çalışmaya dâhil edilmiş, eserler detaylı bir şekilde tanıtılarak kitabeleri okunmuştur. Mezarlık içerisinde yer alan mezar taşları; tipoloji, malzeme, teknik ve bezeme özellikleri ile sanat tarihi açısından değerlendirilmeye çalışılmıştır. Mezarlıkta okunan kitabeli 40 baş taşı olup 7'si kırılmış vaziyettedir. Bunların dışında bütün olmakla birlikte kitabeleri tamamen tahrip olan 5 şahide daha bulunmaktadır. Mezarlıkta kitabeli baş taşlarının yanı sıra bölge açısından farklı olarak bir baba ve oğluna ait lahit üzerinde şahidelerde ki isim, tarih ve dua ibaresinin tekrarlandığı uygulama ile özel bir örnek olarak karşımıza çıkmaktadır. Çamlık Mezarlığında mezarların ve şahidelerin çoğu kırılmış, taşınmış, 
mezarlar yer yer toprak altında kalmış veya taşların yerleri değiştirildiğinden mezar sayısı ile ilgili kesin ifade kullanmak mümkün olmamıştır.

İncelenen mezarlar, mezar tipolojisi olarak 14'ü şahideli toprak mezar' ${ }^{1}$, 16's1 şahideli üzeri açık lahit (sanduka) mezar² (Tibet-Işın-Yelkenci: 1996, 244), 5'i ise şahideli çerçeve mezar ${ }^{3}$ (Tibet-Işın-Yelkenci: 1996, s.246; Tuncel: 2005, 226-229; Tuncel: 2004, 26-38) şeklinde üç farklı tipte mezarların biçimlendiği görülmektedir. Beş ${ }^{4}$ örnekte ise şahideler yerinden çıkarıldığ için bunların mezar tipolojisi tespit edilememiştir. Lahit ve çerçeve mezarların tek veya iki kademeli kaideler üzerinde oturtularak malzeme ve işçiliğin mezarlarda farklılaştığ 1 görülmektedir. Şahideler dikdörtgen prizma biçimindeki mezarların üzerinde açllan yuvalara yerleştirilmiştir. Lahit ile çerçeve mezarların bazıları köşelere yerleştirilen mono blok taşlarla sınırlanarak aralar moloz taşlarla örülerek doldurulmuştur. Daha kaliteli malzemenin kullanıldığı lahit ve çerçeve mezarlarda ise kaidenin üzeri ve kapak kısmı korniş şeklinde profillendirilerek mezarların yüzeylerindeki kademeli panolarla da hareketlilik sağlanmıştır. Lahitleri oluşturan taşların üstte demir kenetlerle birbirine tutturularak bağlandığı görülmektedir. Şahidelerin çoğu günümüzde yerlerinden çıkarılmış, toprak mezarlar kaybolmuş, lahit ve çerçeve mezarlarda ise tahribat çok fazladır.

İncelenen şahideler form bakımından düşey dikdörtgen prizmal gövdeli olup aynı formun yukarı doğru genişleyen ve tek örnekte ise aşağı doğru genişleyen biçimleri şeklinde uygulanmıştır. Mezarda yatan kişinin kimliği ile paralel şekillenen şahidelerin başlıkları (Çal, 2000:206-225; Laqueur: 2010, 138-140; Işın: 1994, s.439-441; İşli: 2009, 56-115) ise kadın ve erkek mezar taşlarında farklılaşmaktadır. Bu mezarlıkta kadınlara ait başlıkların 2'si üçgen ${ }^{5}$ ve 5 'i sivri' ${ }^{6}$ kemer formlu olarak sade tepelikler şeklinde biçimlenmiştir. Erkek başlıkları ise 18 'i fes, 5'i sarık ve 1'i kavuk olarak değişirken özellikle fesin ağırlıklı olarak dönemin gereği tercih edildiği anlaşılmaktadır. $\mathrm{Tek}^{7}$ örnekte bitkisel başlık ve bir $^{8}$ örnekte ise başlı̆̆ın formu farklı olarak diğerlerinden ayrılmaktadır.

Mezarlıkta yer alan şahidelere genel olarak bakıldığında iki baş taşının aynı mezar üzerinde, ayakucunda bulunduğu dikkat çekmektedir. Dolayısıyla zamanla şahidelerin yerlerinin değiştirildiği ve bazı düzenlemeler yapıldığ

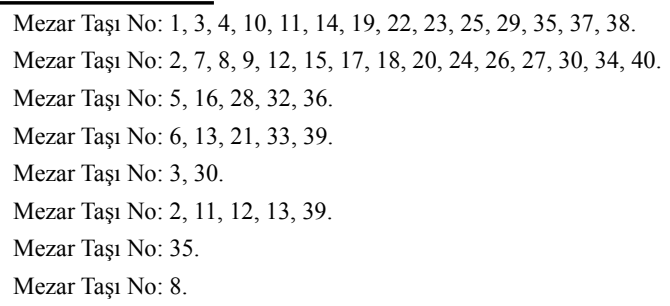


anlaşılmaktadır. Diğer önemli bir husus ise ayak taşlarının bir kaçı dışında çoğunun yerlerinden çıkarıldığı ve bu taşların hangi mezara ait olduğunun bilenememesidir. Ayak taşlarının yerlerinde olup fakat tamamen sade olan örnekleri azda olsa vardır. Bunun yanı sıra tespit ettiğimiz 11 ayak taşı ise ölümle ilgili sembolik anlamlar içeren bitkisel motiflerle bezendiği görülmektedir (Ersoy, 2002: 91-95; Önder, 1970: 10; Y1lmaz, 2010: 19-20- Haseki, 1977: 47; Barışta, 2002: 123-136; Akar, 1991: 73-78; Biçici, 2009: 109-150; Doğanay, 1998: 261-267; Oğuz, 1983: 24-27; Pektaş, 2001: 85-91).

Türk sanatında süsleme anlayışı, XVIII. yy. da Batılılaşma hareketleri ile birlikte değişikliğe uğramıştır. Bu dönemde doğadan stilize edilmiş bitkisel kompozisyonlar, çeşitli vazolar içerisinde meyve tasvirlerini içeren natürmortlar, farklı çiçeklerin hareketli bir şekilde bezemeye girdiği görülmektedir. Sanatın birçok kolunda özgün izler bırakan Barok-rokoko-ampir gibi üslupların etkilediği bezeme, mezar taşlarına kadar yansımıştır. Bu kompozisyonlarda stilize edilen motiflerin karakteristik çizgileri korunmaya çalışılmış ve üsluplaştırılan bitkiler oldukça yalın ele alınmıştır. Şahidelerin yüzeyine bezenen kompozisyonlarda bitkiler genellikle kaide ve kulpları olan vazolardan çıkarılmış, bazen de zeminden başlatılarak "S" kıvrımlarıyla tüm alanı doldurmuştur. Asıl kompozisyonu oluşturan tek veya çiftli ele alınan dallar, uçları kıvrılarak veya farklı yönlere helezonlar çizer şekilde bezenmiştir. Burada kalan 11 ayak taşı bezeme açısından zengin olup uygulanan kompozisyonlarda batılılaşmanın etkisiyle stilize edilmiştir. Bu motiflerin her birine dini anlamlar yüklenmiş ve hiçbiri rastgele seçilmemiştir. Estetik kaygılarla oluşturulan motiflerin ikonografik olarak derin anlamlar taşıdığı aynı zamanda yatan kişinin genel özellikleri ile de doğru orantılı olduğu gerçektir (Tali, 2012, 117; Tali, 2013, 191). Bunlar arasında yaşam ve ölüm sembolü servi, asma dalları, üzüm, serviye dolanan çiçekler, vazodan çıkan soyut dallar üzerinde çiçekler şeklinde iken bir örnekte ise geometrik olarak süsleme değişmektedir. Bezemeli ayak taşları içerisinde tek örnekte ise üçgen şekilde yelpazeye benzer bir motif işlenmiştir. Plastik açıdan farklı ve özellikli örneklerin bulunduğu şahidelerdeki süsleme; bitkisel, geometrik ve nesneli bezeme şeklindedir.

Mezar taşlarında kullanılan malzeme mermer olup lahit ve çerçeveler de malzeme kesme taş şeklinde değişmektedir. Malzeme olarak soylu ve en uzun ömürlü olan mermer dayanıklılığı nedeniyle mezar taşlarında en çok tercih edilen malzeme olmuştur. Kitabeler oyma tekniği ile işlenmiş derinlikleri alçak kabartmadır, yüksek kabartma tekniğinde örnekler azda olsa bulunmaktadır. Kazıma tekniğinin hiç kullanılmadığı şahidelerde işçilik kalitelidir. Ayak taşları üzerindeki bitkisel bezemeler ise yüksek kabartma şeklindedir. Osman11 döneminde Batılılaşma döneminin karakteristik süsleme unsurlarının etkisi mezar taşlarındaki bezemeye de yansımış bu anlamda özgünlüğünü devam 
ettiren en önemli öğe ise şahidelerdeki hat sanatı olmuştur. Hat sanatı açısından da şahidelerde zengin örneklerin bulunduğu görülmektedir. Baş taşlarının hepsi sadece kitabelerin yazıldığ sade örnekler olarak biçimlenirken tek ${ }^{9}$ örnekte köşeler kır çiçekleri ile bezenmiştir.

Çamlık Mezarlığında yer alan baş taşlarının kitabeleri okunmuş ve bu doğrultuda çıkarılan sonuçlar şu şekilde değerlendirilmiştir. Şahidelerde kitabelerin ilk başlangıç cümleleri genellikle Arapça bir ifade ile başlamaktadır. Şahidelerin başlangıç ifadelerinden sonraki metinler ise Osmanlı Türkçesi ile yazılmıştır. Kitabelerdeki metinler 23'ü celi sülüs hatla, 12 'si celi talik hatla, 5 ' $\mathrm{i}$ ise nesih hatla yazılmıştır. Kitabeler, serbest olarak, düz veya diyagonal satırlar hâlinde kabartma olarak amacına uygun başlangıç cümlesi, manzum kalıplarla yazılan ifadeler ile ölenin kimlik bilgisi, dua ve tarih ibaresi ile tamamlanmıştır. Bu şahidelerin kitabeleri 3'ü mensur diğer kitabelerin hepsi ise manzum şekilde oluşturulmuştur. Manzum örneklerde ölüm, ayrılık, gafillik, hüzün, çekilen hastalıklar veya sıkıntılar ve dua isteme gibi ricalar şeklinde ifade edilmektedir. Kitabelerin Arapça ile yazılan başlangıç ifadelerinde en sık kullanılan yakarış on örnekte "Hüve'l-Baki (O Ebedidir)" dir. On dört örnekte “Ah Mine'l-Mevt (Ah Acı Ölüm)" ifadesi Geç Osmanlı dönemi toplumunda üst tabakanın manevi değişiminin bir göstergesidir. Çünkü İslami bakış açısına göre bu ifade ters olup ölüm daha iyi bir hayata geçiştir (Laqueur, 2010:83). Bir örnekte ise " $Y a \mathrm{Hu}$ (Allah) " ile başlarken bunun dışında sekiz örnek ise tarih ibaresi ile başlamaktadır.

Kitabelerin en önemli bölümü, ölenin kimlik bilgilerinin verildiği kısımdır. Okunan kitabelerden şahidelerin 30 ' $\mathrm{u}^{10} \mathrm{erkek}$, 7'si ${ }^{11}$ kadın ve 3 'nün ${ }^{12}$ ise cinsiyeti belirlenememiştir. Kitabelerde erkek ve kadın isimleri genellikle yazılırken çoğunda ölen kişinin mensup olduğu Hatipoğlu, Küplüoğlu, Başoğlu, Kılıçoğlu, Uzun Hacığlu ve zade eklenmesi ile bir soyadı şeklinde aile isimleri ile özellikle baba isimleri de kayıt edilen bilgilerdendir. Bu lakapların dışında 9 kitabede de "el Hac ve Hacı" olarak sonradan kazanılan bir unvan isimlere eklenmiştir. Kadınlar için en çok kullanılan unvan 4'ü "hanım" ve 1'i "hatun" olup bir örnekte de doğrudan ölenin ismi ile anılmışlardır. Erkek baş taşlarında ise 2'si "bey", 5'i "ağa" ve en çok 19 kez belli bir eğitime sahip olanlar için kullanılan "efendi" unvanı tekrarlanmıștır. "Uzun" ve "Kara" olarak kullanılan iki lakapta ise doğrudan kişinin fiziksel özellikleri de verilmiştir. Mezarlıkta medfun olanların Ünye, bunun dışında ise Trabzon, Vakfikebir, Rize, Batum, Arhavi, Görele, Hopa, Akçaşehir, Adalı?, gibi merkezlerden ge-

\footnotetext{
9 Mezar Taşı No: 4.

10 Mezar Taş1 No: 1, 4, 5, 6, 7, 8, 9, 10, 14, 15, 16, 17, 18, 19, 20, 21, 22, 23, 24, 25, 26, 27, 28, 29, 31, 32, 34, 35, 37, 38.

11 Mezar Taşı No: 2, 3, 11, 12, 13, 30, 39.

12 Mezar Taşı No: 33, 36, 40.
} 
len muhacirler olduğu ve bağlı oldukları karyeleri (köyleri) dahi belirtilmiştir. Mezarlıkta bugüne kalan şahidelerin ağırlıklı olarak erkeklere ait olduğu kadınların ise sayıca çok az olduğu görülmektedir. Kitabelerden kumandan, terzi, usta, memur, imam, hatip, hafız, çiçekçi gibi bazı unvan ve meslek isimleri de çıkarılmaktadır. Mezarlıktaki iki şahidede ise 13 ve 18 yaşlarında vefat ettiği belirtilen iki gencin ölüm yaşları da işlenmiştir.

Mezar taşlarının yapılmasının en önemli sebeplerinden biri hiç şüphesiz ölen kişi için istenen duadır. Kitabelerde dua isteme biçimleri çok farklı şekillerde istenmekle birlikte burada incelenen örneklerin 24'ü "ruhuna Fatiha", 1'i "ruhuna el-Fatiha", 3'ü "ruhıyçün Fatiha", 2'i "ruhıyçün el-Fatiha", 2'si "ruhuna ihsan edin bir Fatiha", 1'i "bi hurmet-il Fatiha", 1'i "ruhuna", 1'i "hep görenler Fatiha okusun", şeklinde değişmektedir. Tek örnekte ise farklı olarak dua ibaresi yer almamaktadır.

Mezarlıkta kronolojik olarak değerlendirilen şahidelerin en erken tarihlisi $1183 \mathrm{H} . / 1769 \mathrm{M}^{13}$ tarihli, en geç örnekler ise $1338 \mathrm{H} . / 1919 \mathrm{M} .{ }^{14}$ tarihlidir. XVIII. yy. ila XX. yy. aralığına Geç Osmanlı Dönemine tarihlenen mezar taşlarının kırık veya toprağa gömülü birkaç örnek dışında hepsinin üzerinde tarih ibareleri mevcuttur. Kitabelerde 1332 H./1913-1914 tarihinin $7^{15}$ örnekte, 1333 H./1914-1915 tarihinin ise $11^{16}$ örnekte tekrar etmektedir. Şahidelerin 3 'ünde ise iki farklı tarih ibaresi yer almaktadır. Kitabelerdeki tarih ibarelerinde ölüm yılı verilmiş dokuz örnekte ${ }^{17}$ ise Kanunisani (Ocak), Recep, Şaban, Safer, Lam-mim harfi ile kısaltılarak Muharrem-Şevval şeklinde ay adları ile 2 örnekte ${ }^{18}$ 13/19 (Ocak) ölüm günü de tarihe işlenmiştir. Ay adlarının kitabelerde özellikle Arapça yazılması da dikkat çekicidir. Tek ${ }^{19}$ örnekte ise kutsal bir gece "Berat Gecesi” olarak bir kayıt da tarih satırında yerini almıştır.

Ünye Çamlık Fener Altı Mezarlığında değerlendirilen mezar taşlarının öncelikle Karadeniz Bölgesi Ordu Ünye (Çelik: 2012), Rize (Hanoğlu: 2015, C.I-II-III), Trabzon (Eren: 2011), Giresun (İltar: 2005), Samsun (Nefes: 2002), Sinop (Yeni: 2009), Safranbolu (Biçici: 2008, 297-324) gibi sahil kesimindeki örneklerle malzeme, form ve teknik açıdan benzerlikler göstermektedir. Bununla birlikte mezar taşlarında mermer malzeme kullanımı, hat ve işçiliklerin özenle ele alınması formların çeşitliliği ve bezeme doğrultusunda ise Bursa (Mermutlu-Öcalan:2011), Edirne (Baş:2009) ve İstanbul (Laqueur, 2010:7-79) gibi önemli merkezlerdeki örneklere döneme özgü üsluplarla pa-

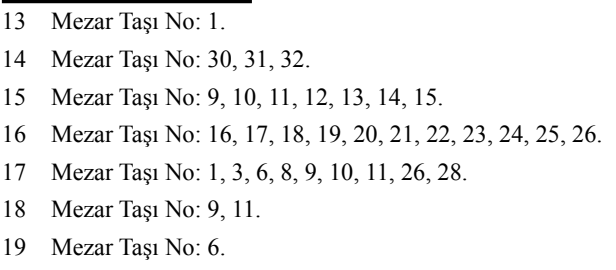


ralel özellikler gösteren mezar taşları olarak biçimlenmektedir. Bu eserlerin buraya siparişle mi getirtildiği yoksa dışarıdan gelen usta grupları tarafından mı gerçekleştirildiği tam olarak bilinmemektedir. Ordu iline bağlı bir ilçe konumundaki merkez, Osmanlı Dönemi'nde uygun coğrafi konumu sebebiyle önemli bir liman ve ticaret merkezi hâline gelmiştir. Ünye 1864 tarihinde Trabzon Vilayeti Canik Sancağına bağlı olarak dört yıl sancaklık yapmıştır. Bu özelliği merkezde bulunan tarihi yapılara da yansımış ve zengin bir kültürel miras bırakılmıştır, mezar taşları da bunlar arasında yerini almaktadır.

\section{Sonuç}

Ünye Çamlık Feneraltı Mezarlığında bulunan kırk mezar taşı bilimsel olarak incelenmiş ve bu eserler kayıt altına alınmıştır. Tahribatın fazla olduğu mezarlıkta kırık olan veya kısmen silinmiş olan tüm şahideler transkrip edilerek günümüz Türkçesine çevrilmiş ve özellikle kitabelerin muhtevası üzerinde durulmuştur. Ayrıca mezar tipolojisi, şahidelerin malzeme, teknik, form ve ayaktaşlarının bezeme özellikleri sanat tarihi metodolojisi içerisinde değerlendirilmeye çalışılmıştır. Zengin bir geçmişi barındıran mezarlıkta özellikle farklı yerlerden gelen çok sayıda muhacirerin defnedildiği anlaşılmaktadır. Bununla birlikte asker, memur, imam gibi çok farklı meslek grubuna ait insanların da bulunduğu mezarlıkta özellikle erkek nüfusu ağırlıktadır. En önemli bezemesi üzerindeki yazıtları olan şahidelerden şüphesiz dönemle ilgili en doğru bilgiler elde edilmektedir. Yazılı belgeler olarak mezar taşları aynı zamanda sanat tarihi açısından da dönemin üslup özelliklerini devam ettiren eserlerdir. Çamlık Feneraltı Mezarlığında malzeme, hat ve işçilik açısından mezar taşlarının itinalı ve başkent İstanbul örneklerine paralel özellikler gösterdiği tespit edilmiştir.

Çamlık Mezarlı̆̆ındaki baş taşları sade görünümlü ve mezar taşı yapma geleneğini devam ettiren örneklerdir. İlçenin batısında sahilde yer alan mezarlığın içerisinde bir yürüyüş yolu olup yan tarafın ise bir piknik alanı olarak kullanılıyor olması mezar taşlarının her türlü tehlikeye açık olduğunun kanıtıdır. Çalışma süresince bile yerde olan bazı örneklerin kaybolduğu, başlıkların kırıldığ 1 ve lahitlerin parçalandığ1 görülmüştür. Özellikle şahidelerin üzerinde oluşan likenlerin temizlenmesi için yapılan çalışma ise kitabelere çok fazla zarar vermiştir. Şahidelerin yağlı boya ile tamamının veya kitabelerinin üzerinin kısmen boyanması dolayısıyla bazı kitabelerin okunması zorlaşmıştır. Son olarak mezarlıktaki şahidelerin restorasyonu yapılarak sayıları daha fazla azalmadan bu eserlerin yerlerinde korunmaları gerekmektedir. Ölüme rağmen ölenin adını ölümsüzleştirmek için yapılan bu eserlerin en önemli amacı ise ölen için istenen dualardır. 


\section{Kaynaklar}

AKAR, Azade (1991), "Yüzyıllar Boyunca Mezar Yazıtlarında Süslemeler" Atatürk Konferansları VI (1973-1974), s.73-78, Ankara, Türk Tarih Kurumu Yayınları.

ARGAN, Yaşar (2004), İpek Yolu ve Ünye, İstanbul, Ünye Kent Araştırmaları.

BARIŞTA, Örcün (2002), "Göynük Akşemsettin Türbesi Haziresindeki Bitkisel Bezemeli Kadın Mezar Taşları”, VI. Ortaçağ ve Türk Dönemi Kazı Sonuçları ve Sanat Tarihi Sempozyuтu (8-10 Nisan) Bildiriler, Kayseri, s.123-136, Erciyes Üniversitesi Yayınları.

BAŞ Emine (2009), Edirne Beylerbeyi Camii Haziresinde Bulunan Mezar Taşları, Trakya Üniversitesi, SBE., Sanat Tarihi ABD. Basılmamış Yüksek Lisans Tezi.

BİÇİCİ, H.Kamil (2008), "Safranbolu Yörük Köyü Mezarlığında Bulunan Mezar Taşları”, Sosyal Bilimler Dergisi, S.20, s.297-324.

Bİçi̇Ċ, H.Kamil (2009), "Tire Müzesinde Bulunan Süslemeli Mezar Taşlarından Bazı Örnekler (XVIII- XX. yy.)”, Ankara Üniversitesi İlahiyat Fakültesi Dergisi, 50: 1, Ankara, s.109-150.

ÇAL, Halit (2000), “Ístanbul Eyüp'teki Erkek Mezar taslarında Başlıklar” Tarihi, Kültürü ve Sanatıyla III. Eyüpsultan Sempozyumu Tebliğler (28-30 Mayıs), s.206-225. İstanbul, Eyüp Belediyesi Kültür Yayınları.

ÇELİK, Bayram (2012), Ordu İli Ünye İlçesi Hacı Osman Ă̆a Camii Haziresindeki Mezar Taşları, Ondokuz Mayıs Üniversitesi, Sosyal Bilimler Enstitüsü, İslam Tarihi ve Sanatları ABD., Basılmamış Yüksek Lisans Tezi.

DOĞANAY, Aziz (1998), "Eyüp Sultan Camii Civarındaki Bazı Mezarlıkların Natüralist Üslupta Klasik Devir Süslemeleri”, Tarihi, Kültürü ve Sanatıyla II. Eyüpsultan Sempozyumu Tebliğler, s.261-267. İstanbul, Eyüp Belediyesi Kültür Yayınları.

EREN Sevinç (2011), Trabzon İli Gülbahar Hatun Camii Hazireleri ile Küçük İmaret Mezarlığı'ndaki Mezar Taşları, Gazi Üniversitesi Sosyal Bilimler Enstitüsü Sanat Tarihi ABD., Basılmamış Doktora Tezi.

ERSOY, Ayla (2002), “Eyüp’teki Mezar Taşlarında Servi Ağacı Kültü”, Tarihi, Kültürü ve Sanatıyla V. Eyüpsultan Sempozyumu Tebliğler, s.91-95. İstanbul, Eyüp Belediyesi Kültür Yayınları.

HANOĞLU, Canan (2015), Batılılaşma Dönemi Rize Mezar Taşları, Atatürk Üniversitesi Sosyal Bilimler Enstitüsü, Basılmamış Doktora Tezi.

HASEKİ, Metin (1977), Plastik Açıdan Türk Mezar Taşları, İstanbul, İstanbul Devlet Güzel Sanatlar Akademisi Yayınları.

IŞIN, Ekrem (1994), "Mezar Taşları" Dünden Bugüne Ístanbul Ansiklopedisi, C.5, İstanbul, s.438-442.

İŞLİ, H. Necdet (2009), Osmanlı Serpuşları, İstanbul, Ebru Matbaacılık.

İLTAR, Gazanfer (2005), Giresun İli Sahil Şeridindeki Mezar Taşları, Gazi Üniversitesi Sosyal Bilimler Enstitüsü, Sanat Tarihi ABD., Basılmamış Yüksek Lisans Tezi.

LAQUEUR, Hans Peter (2010), “Hüve'l Baki, İstanbul'da Osmanlı Mezarlıklarl ve Mezar Tasları", İstanbul, Tarih Vakfi Yurt Yayınları.

MERMUTLU, Bedri-ÖCALAN Hasan Basri (2011), Tarihi Bursa Mezar Taşları I Bursa Hazireleri, Bursa Büyükşehir Belediyesi Yayınları. 
NEFES, Eyüp (2002), Samsun Yöresinde Bulunan Mezar Taşları, Ondokuz Mayıs Üniversitesi, Sosyal Bilimler Enstitüsü, Basılmamış Doktora Tezi.

OĞUZ, Burhan (1983), Mezar Taşında Simgeleşen İnançlar, İstanbul, Anadolu Aydınlanma Vakfi Yayınları.

ÖNDER, Mehmet (1970), “Konya Mezar Taşlarında Şekil ve Süsler” Türk Etnografya Dergisi, S.XII-1969, s.5-16, Ankara.

PEKTAŞ, Kadir (2001), Bitlis Tarihi Mezarlıkları ve Mezar Taşları, Ankara, Kültür Bakanlığı Yayınları.

TALİ, Şerife (2013), "Kayseri Tavlusun Köyü Mezarlığında Bir Grup Bezemeli Mezar Taşları I”, Prof. Dr. Hakkı ÖNKAL'A Armağan, s.165-192, LIV-LVI., İzmir, Dokuz Eylül Üniversitesi Yayınları.

TALİ, Şerife (2012), “Kayseri Tavlusun Köyünde Bezemeli Mezar Taşları-II”, Atatürk Üniversitesi Güzel Sanatlar Fakültesi Dergisi/Journal Of Fıne Arts Faculty, S. 21, Erzurum, s.97-124.

TİBET, Aksel-IŞIN Ekrem-YELKENCİ Dilek (1996), "Yenikapı Mevlevîhânesi Haziresi" Islam Dünyasında Mezarliklar ve Defin Gelenekleri Cimetiéres et Traditıons Funéraires Dans Le Monde Islamıque", Ankara, Türk Tarih Kurumu Yayınları.

TUNÇEL, Gül (2005), “Üsküp Alaca Camii Haziresi’ndeki Şahideler”, Hacettepe Üniversitesi Edebiyat Fakültesi Dergisi, C. 22, S. 1, Ankara, s.215-236.

TUNÇEL, Gül (2004), “Üsküp Sultan Murad Paşa Camii Haziresi’ndeki Mezartaşları”, Bilge Dergisi, S.43, s.20-38.

YENİ, Özgür (2009), Sinop Arkeoloji Müzesinde Sergilenen Türk-İslam Dönemi Mezar Taşları, Selçuk Üniversitesi, Sosyal Bilimler Enstitüsü Sanat Tarihi ABD. Türk Dünyası ve Ortaçağ Kültürleri Arkeolojisi Bilim Dalı, Basılmamış Yüksek Lisans Tezi.

YILMAZ Hayri (2010), İstanbul'daki Türk Inanç Kaynaklı Motifli Tarihi Mezar Taşlarının Bozulma Nedenleri ve Restorasyon Yöntemleri, Gazi Üniversitesi Fen Bilimleri Enstitüsü, Yapı Eğitimi ABD., Basılmamış Yüksek Lisans Tezi.

https://www.unye.bel.tr 


\section{FOTOĞRAFLAR}

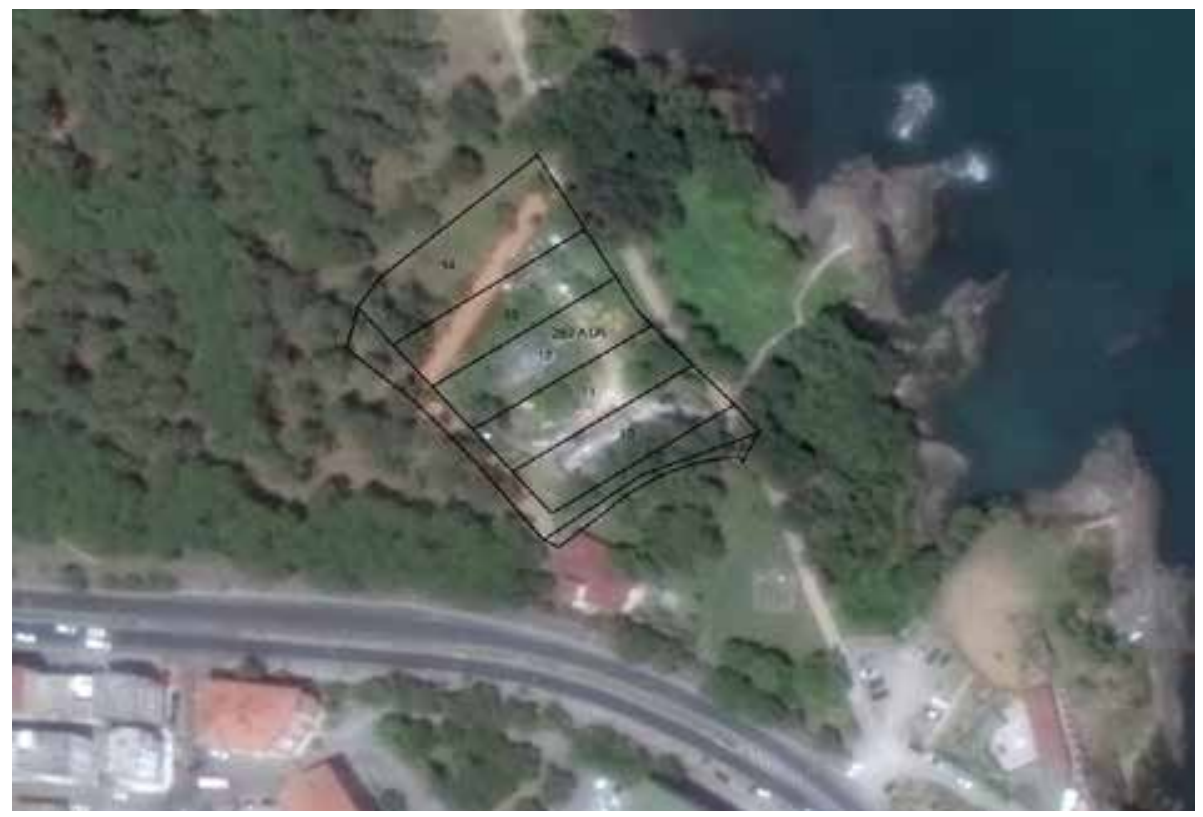

Mezarlık Uydu Görüntüsü ( google earth’den alınmıştır) 


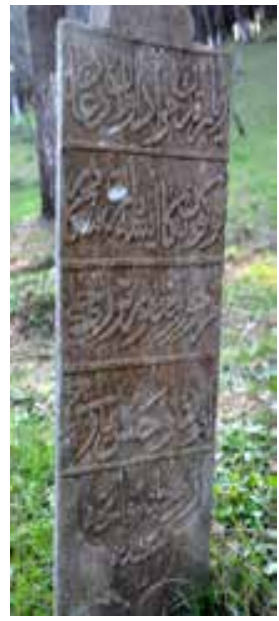

Mezar Taşı No: 1

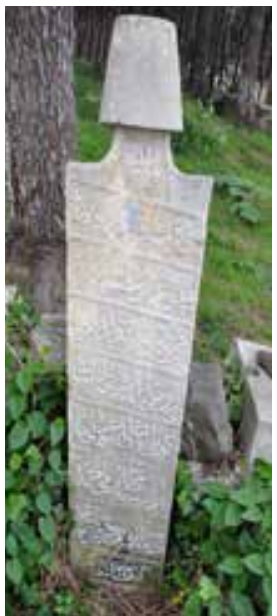

Mezar Taşı No: 5

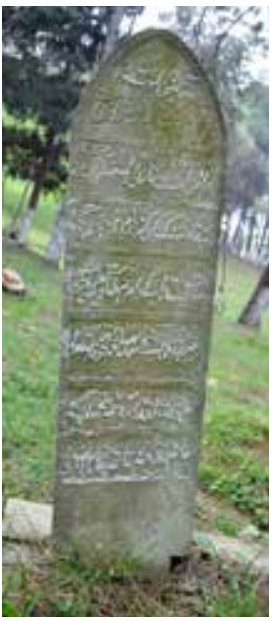

Mezar Taşı No: 2

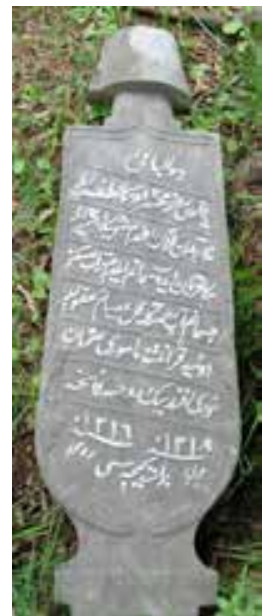

Mezar Taşı No: 6

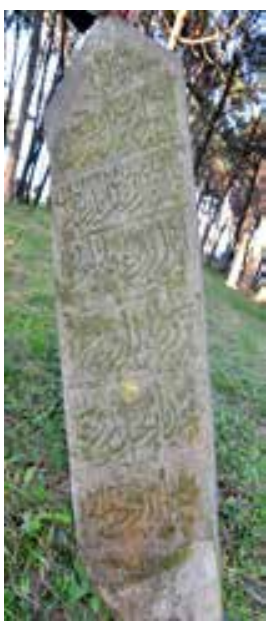

Mezar Taşı No: 3

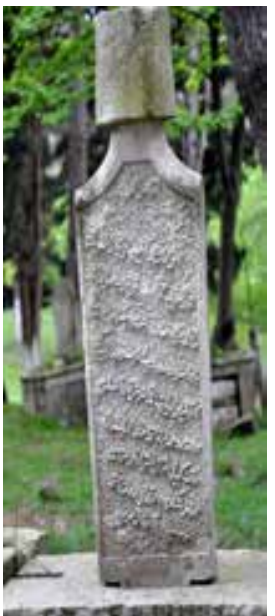

Mezar Taşı No: 7

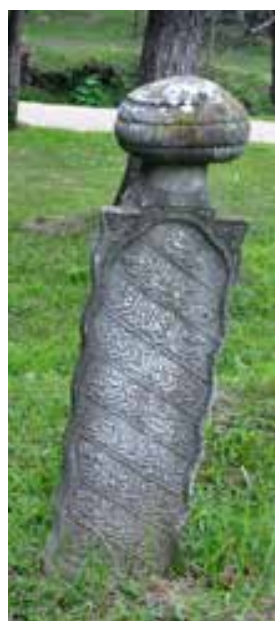

Mezar Tașı No: 4

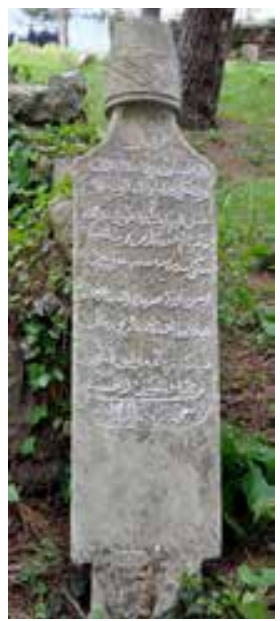

Mezar Taşı No: 8 


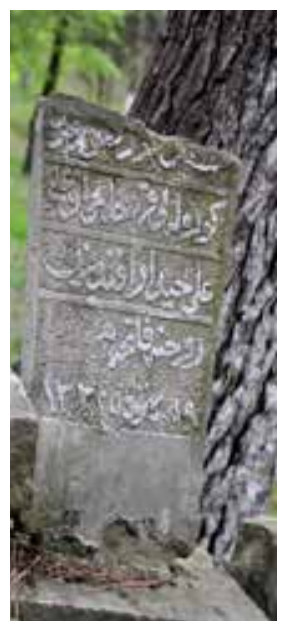

Mezar Taşı No: 9

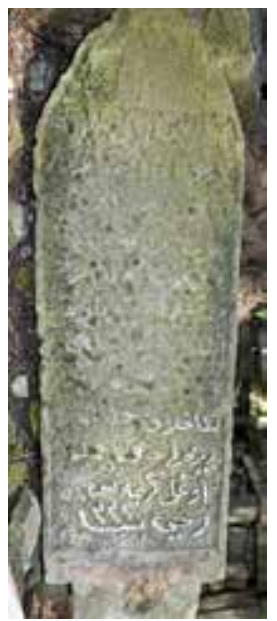

Mezar Taşı No: 13

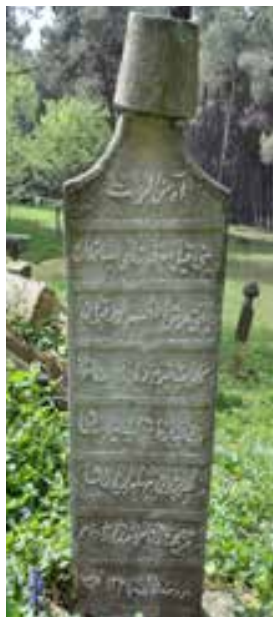

Mezar Taşı No: 10

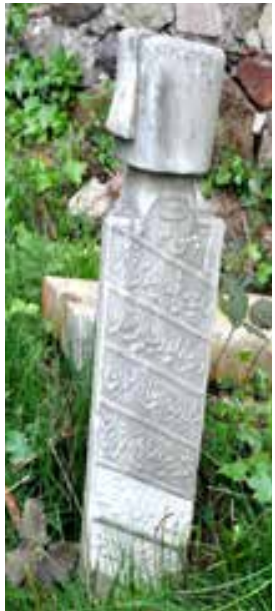

Mezar Taşı No: 14

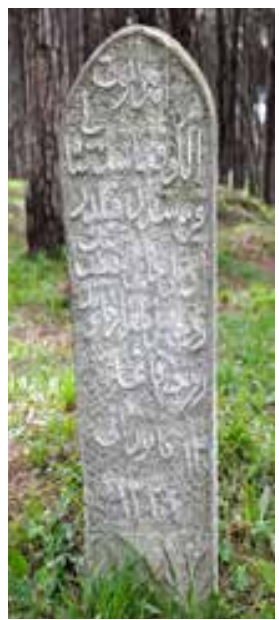

Mezar Taşı No: 11

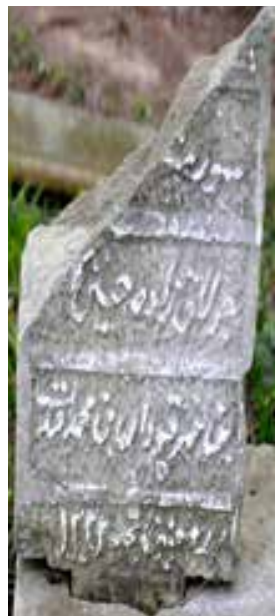

Mezar Taşı No: 15

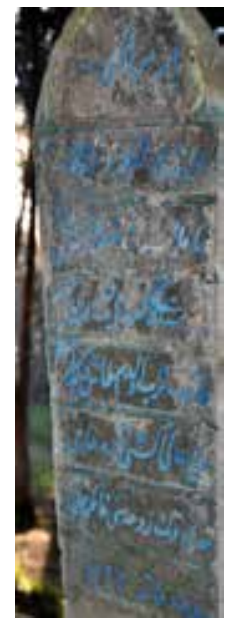

Mezar Tași No: 12

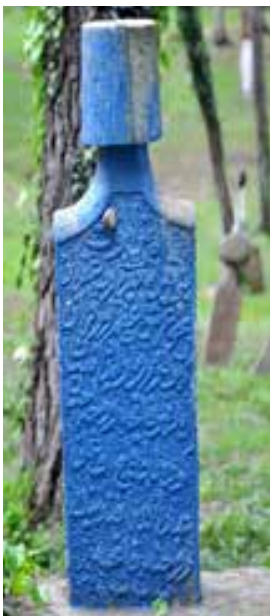

Mezar Taşı No: 16 


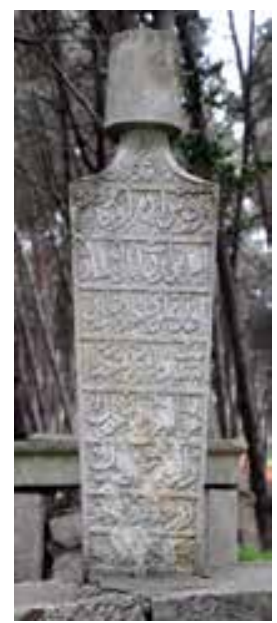

Mezar Taşı No: 17

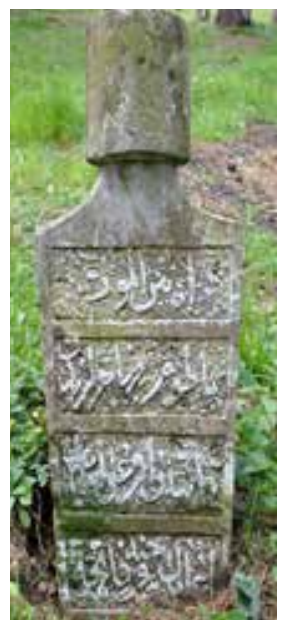

Mezar Taşı No: 19

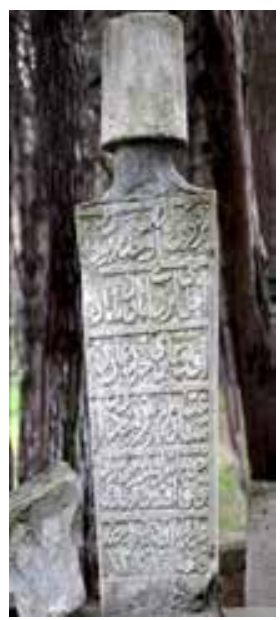

Mezar Taşı No: 18

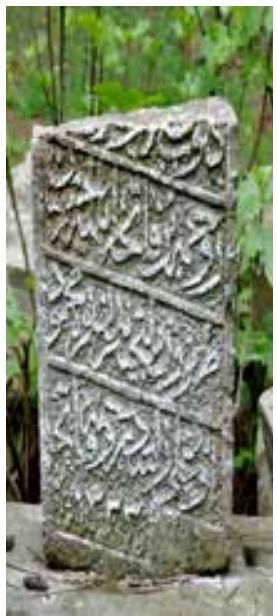

Mezar Taşı No: 20

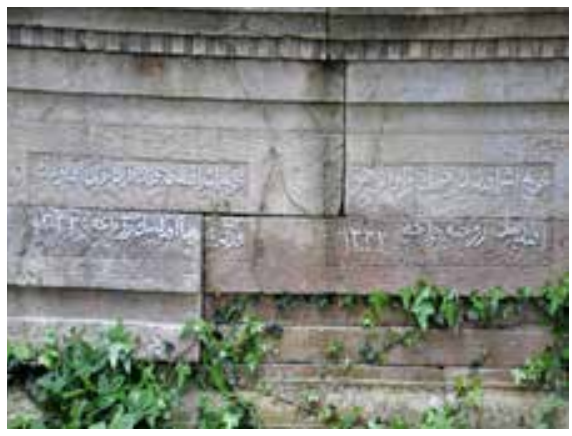

Lahit Üzerinde Yer Alan Kitabeler

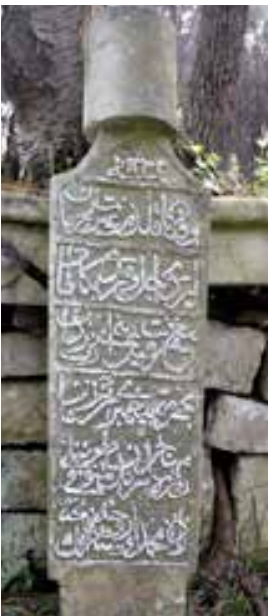

Mezar Taşı No: 21

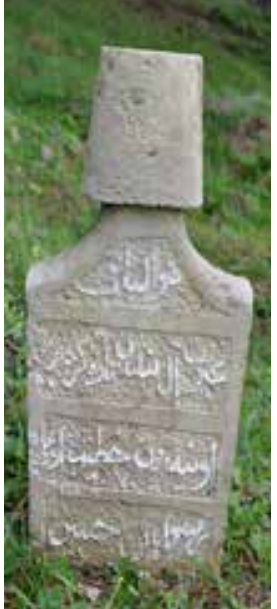

Mezar Taşı No: 22 


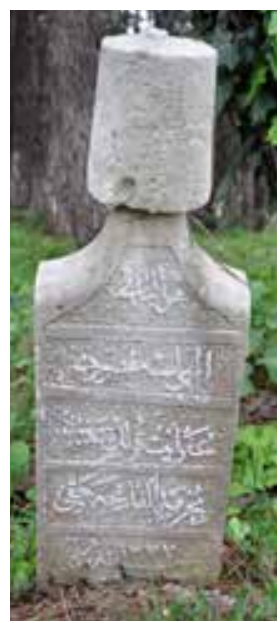

Mezar Taşı No: 23

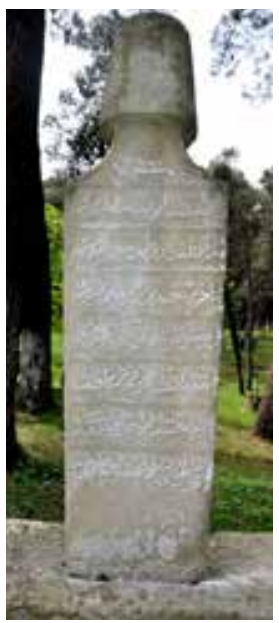

Mezar Taşı No: 27

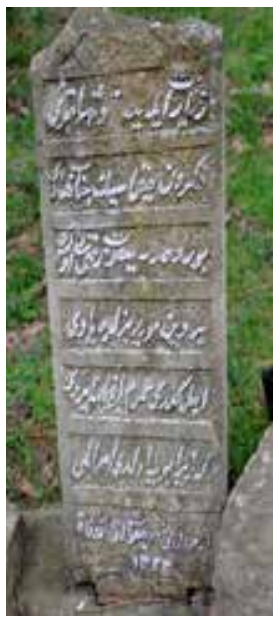

Mezar Taşı No: 24

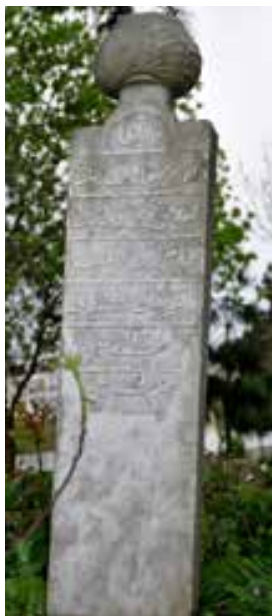

Mezar Taşı No: 28

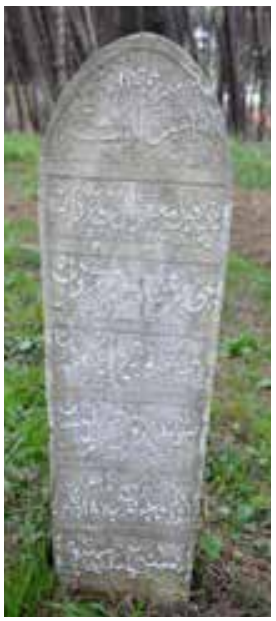

Mezar Taşı No: 25

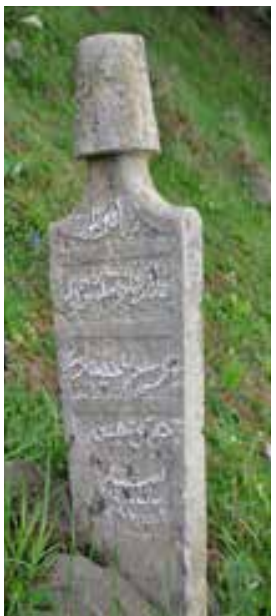

Mezar Taşı No: 29

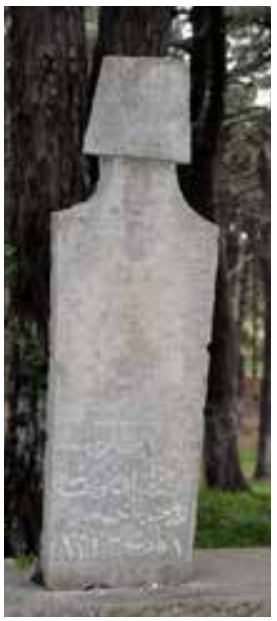

Mezar Taşı No: 26

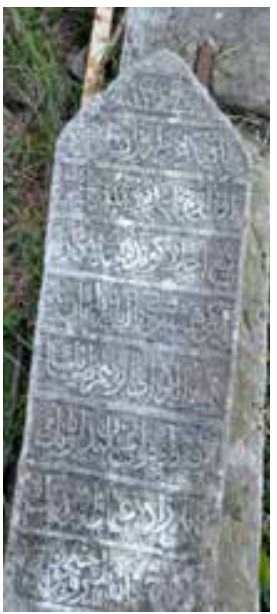

Mezar Taşı No: 30 


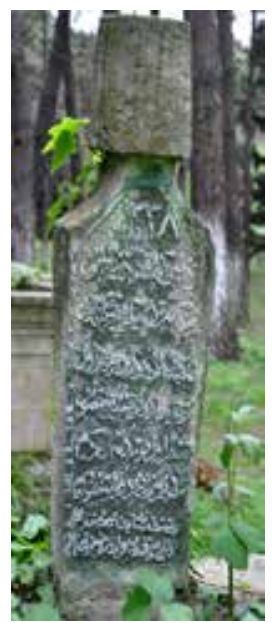

Mezar Taşı No: 31

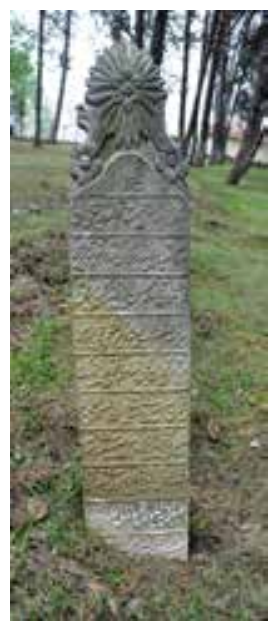

Mezar Taşı No: 35

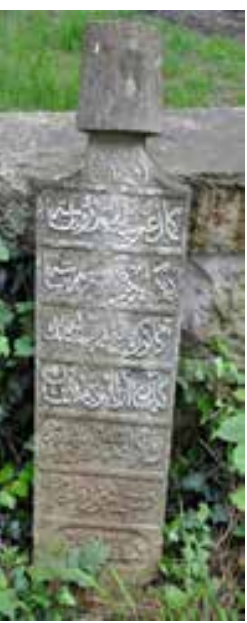

Mezar Taşı No: 32

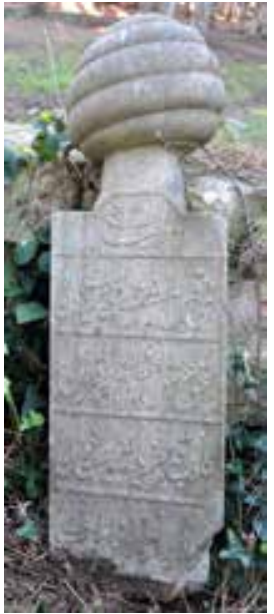

Mezar Taşı No: 36

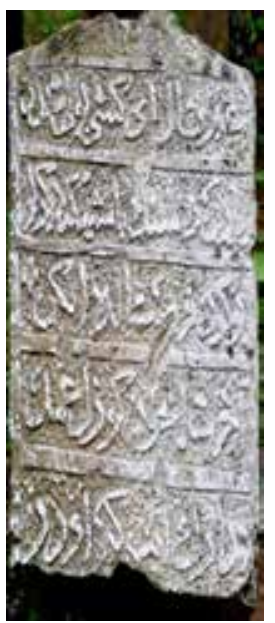

Mezar Taşı No: 33

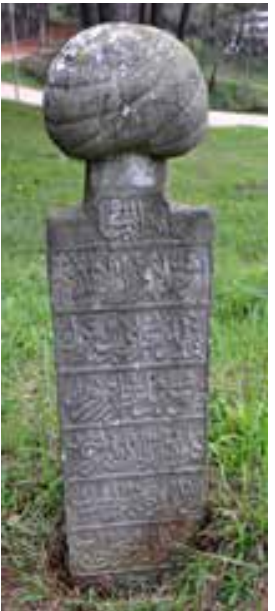

Mezar Taşı No: 37

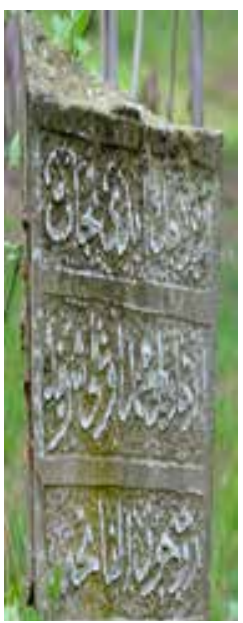

Mezar Taşı No: 34

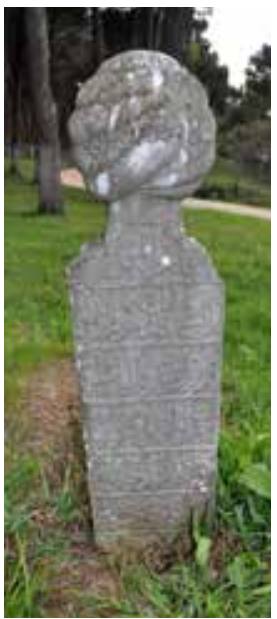

Mezar Taşı No: 38 


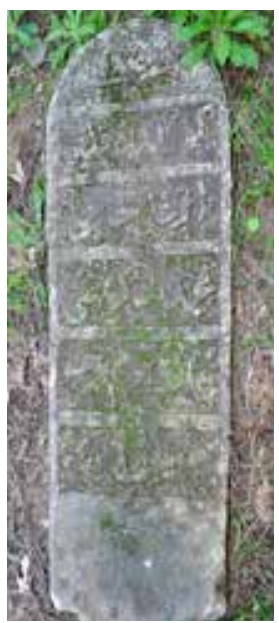

Mezar Taşı No: 39

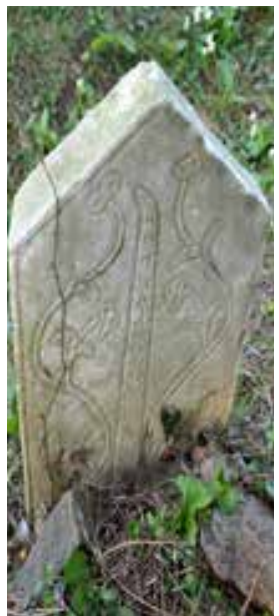

Ayak Taşı No:2

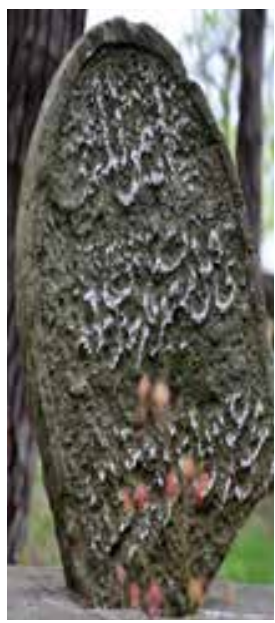

Mezar Taşı No: 40

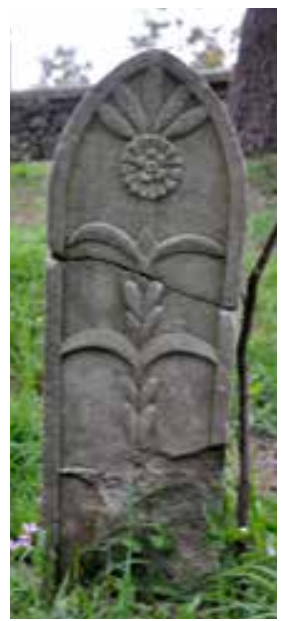

Ayak Taşı No:3

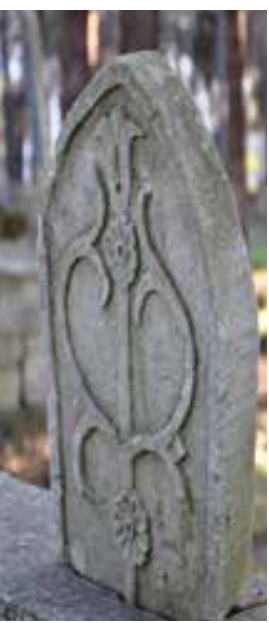

Ayak Taşı No:1

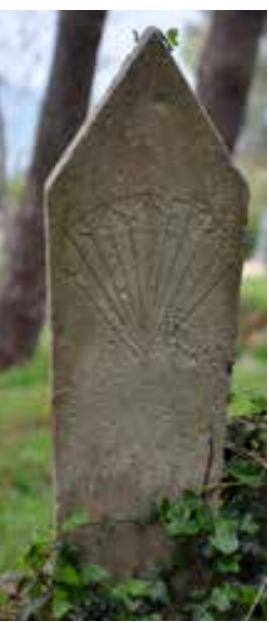

Ayak Taşı No:4 


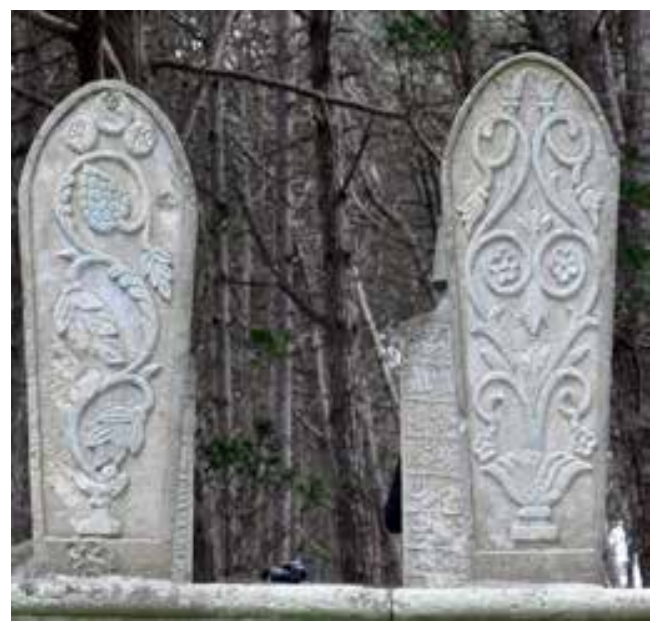

Ayak Taşı No:5-6

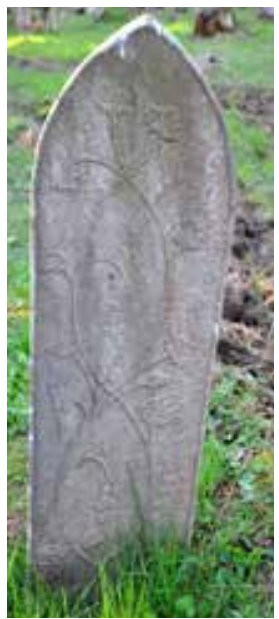

Ayak Taş1 No:8

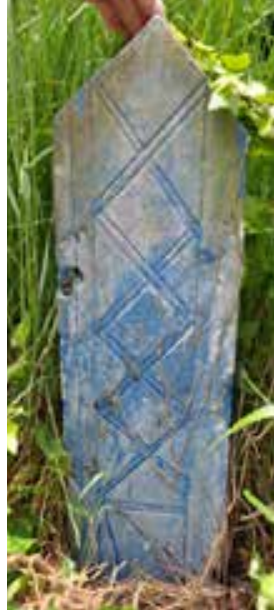

Ayak Taşı No:9

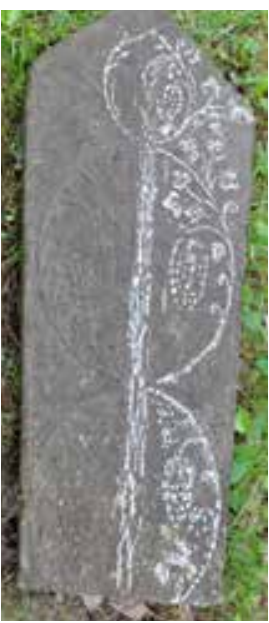

Ayak Taşı No:7

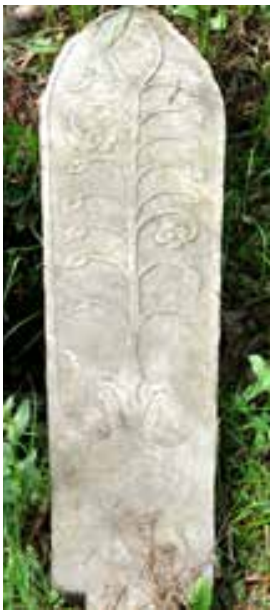

Ayak Taş1 No:10 


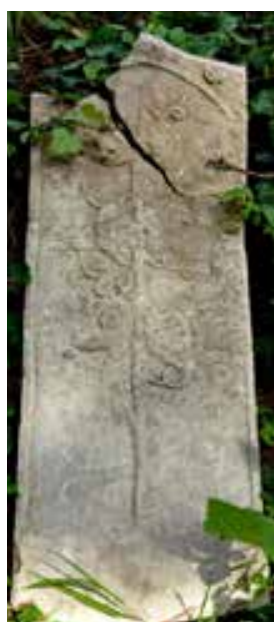

Ayak Taşı No:11

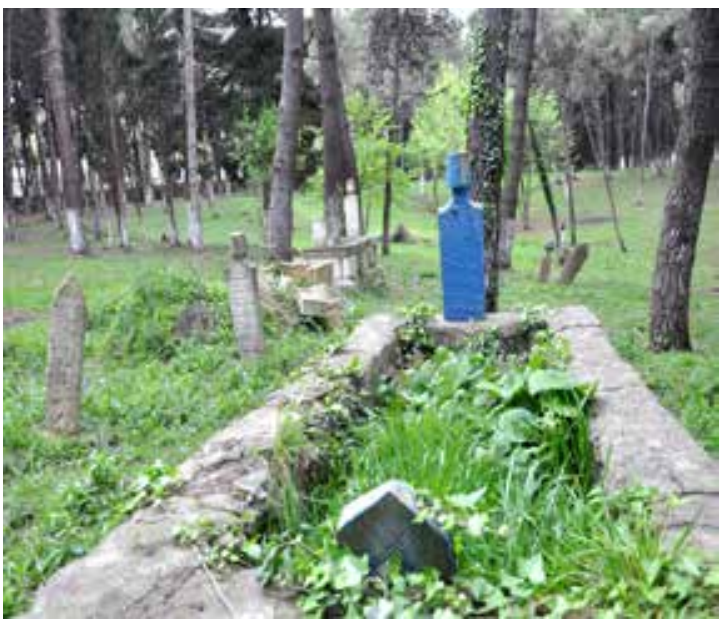

Mezarlıktan Genel Görünüm 